\title{
\#USGS
}

science for a changing world

Prepared in cooperation w ith the National Park Service

Surface- and Ground-Water M onitoring and M apping of Selected Features at the Blue Ridge Parkw ay

Mt. Pisgah Campground, Hayw ood County,

North Carolina, 2002

U.S. Geological Survey Open-File Report 2004- 1073

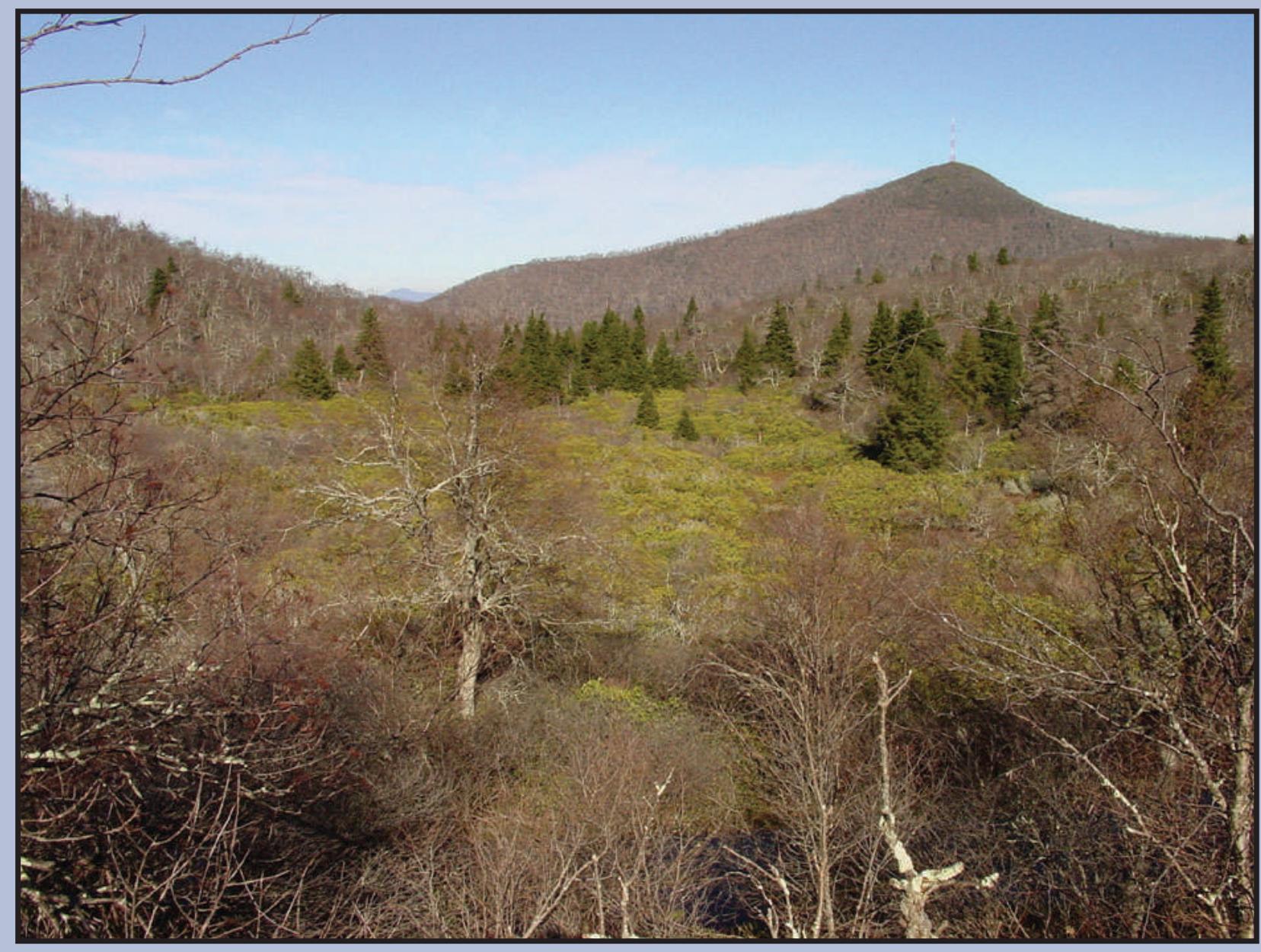


Cover. Mt. Pisgah, Haywood County, North Carolina. 


\section{Surface- and Ground-Water Monitoring and Mapping of Selected Features at the Blue Ridge Parkway Mt. Pisgah Campground, Haywood County, North Carolina, 2002}

By Douglas G. Smith

Prepared in cooperation with the National Park Service

U.S. Geological Survey Open-File Report 2004-1073 


\title{
U.S. Department of the Interior Gale A. Norton, Secretary
}

\author{
U.S. Geological Survey \\ Charles G. Groat, Director
}

\section{U.S. Geological Survey, Reston, Virginia: 2004}

For sale by U.S. Geological Survey, Information Services

Box 25286, Denver Federal Center

Denver, CO 80225

For more information about the USGS and its products:

Telephone: 1-888-ASK-USGS

World Wide Web: http://www.usgs.gov/

Any use of trade, product, or firm names in this publication is for descriptive purposes only and does not imply endorsement by the U.S. Government.

Although this report is in the public domain, permission must be secured from the individual copyright owners to reproduce any copyrighted materials contained within this report.

Suggested citation:

Smith, D.G., 2004, Surface- and ground-water monitoring and mapping of selected features at the Blue Ridge Parkway Mt. Pisgah campground, Haywood County, North Carolina, 2002: U.S. Geological Survey Open-File Report 2004-1073, $33 p$. 


\section{Contents}

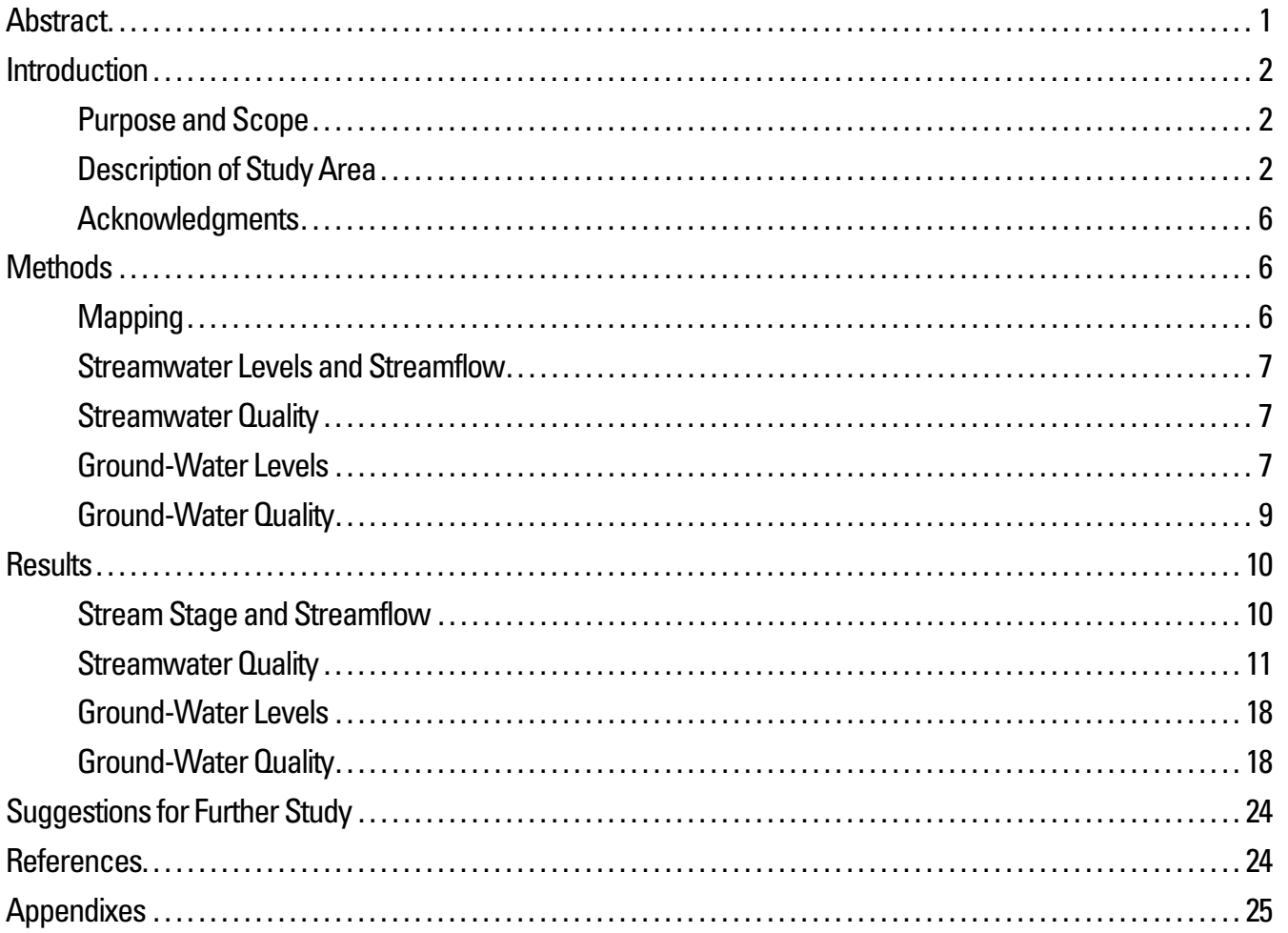

\section{Figures}

1. Map showing the location of the Mt. Pisgah campground in Haywood County, North Carolina......3

2. Map showing selected features and data-collection sites at the Mt. Pisgah campground, Haywood County, North Carolina ...............................................

3. Mt. Pisgah campground area map produced by a global positioning system survey

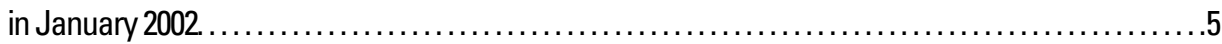

4. Photographs of the downstream side of the double corrugated metal pipe (CMP) culvert where the U.S. Geological Survey gaging station was located at the Mt. Pisgah campground. ......8

5. Photographs of the U.S. Geological Survey gaging station that was built to monitor water levels in the stream flowing from the natural area in the center of the Mt. Pisgah campground ...........9

6. Hydrograph of daily mean steamflow values at unnamed tributary to Pisgah Creek at Flat Laurel Gap at the Mt. Pisgah campground.

7-11. Hydrographs of periodic water levels measured in shallow wells and piezometers at the Mt. Pisgah campground, Haywood County, North Carolina:

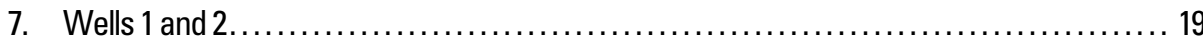

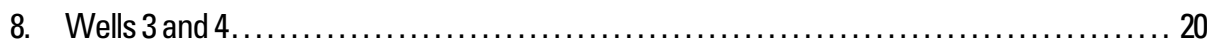

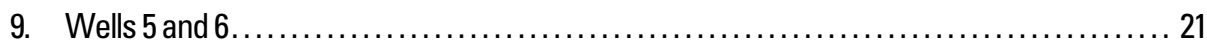

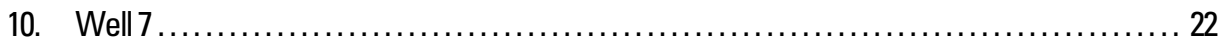

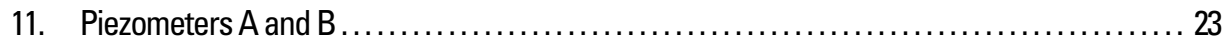




\section{Tables}

1. Daily mean discharge recorded during calendar year 2002 at Mt. Pisgah campground,

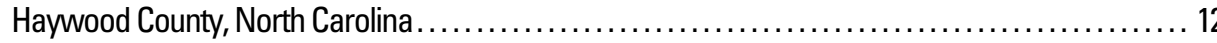

2. Water-quality data from an unnamed tributary to Pisgah Creek at Mt. Pisgah campground, Haywood County, North Carolina, April 23 and September 11, 2002 ...................... 13

3. Selected water-quality data from samples collected in shallow wells and an unnamed tributary to Pisgah Creek at Mt. Pisgah campground, Haywood County, North Carolina, 2002 .... 15

\section{Appendix Tables}

A1. Maximum, minimum, and mean daily streamflow values for calendar year 2002 at Mt. Pisgah campground, Haywood County, North Carolina.

A2. Water-level data from shallow wells and piezometers at the Mt. Pisgah campground, Haywood County, North Carolina.

\section{Conversion Factors and Datums}

\begin{tabular}{lcl}
\hline Multiply & By & To obtain \\
\hline & Length & \\
\hline foot $(\mathrm{ft})$ & 0.3048 & meter $(\mathrm{m})$ \\
\hline & Flow rate & \\
\hline cubic foot per second $\left(\mathrm{ft}^{3} / \mathrm{s}\right)$ & 0.02832 & cubic meter per second $\left(\mathrm{m}^{3} / \mathrm{s}\right)$ \\
\hline
\end{tabular}

Temperature in degrees Celsius $\left({ }^{\circ} \mathrm{C}\right)$ may be converted to degrees Fahrenheit $\left({ }^{\circ} \mathrm{F}\right)$ as follows:

${ }^{\circ} \mathrm{F}=\left(1.8 \mathrm{x}^{\circ} \mathrm{C}\right)+32$

Vertical coordinate information is referenced to the National Geodetic Vertical Datum of 1929 (NGVD29).

Horizontal coordinate information is referenced to the North American Datum of 1983 (NAD83).

Concentrations of chemical constituents in water are given in milligrams per liter (mg/L).

\section{Abbreviations and Acronyms}

CMP

$\mathrm{col} / 100 \mathrm{~mL}$

GPS

NPS

NWQL

PVC

RV

USGS corrugated metal pipe

colonies per 100 milliliters

global positioning system

National Park Service

National Water Quality Laboratory

polyvinyl chloride

recreational vehicle

U.S. Geological Survey 


\title{
Surface- and Ground-Water Monitoring and Mapping of Selected Features at the Blue Ridge Parkway Mt. Pisgah Campground, Haywood County, North Carolina, 2002
}

\author{
By Douglas G. Smith
}

\section{Abstract}

During 2002, a baseline study of hydrologic conditions was conducted, and selected features were mapped within the Mt. Pisgah campground on the Blue Ridge Parkway in Haywood County, North Carolina. Field surveys were performed by using global positioning system equipment one time (January 2002) during the study to locate hydrologic and other types of features in the study area. Water-level and streamflow data and seasonal water-quality samples were collected from a stream that receives all surface-water drainage from the campground area. During 2002, water levels (stage) in the stream ranged from 1.09 to 1.89 feet above gage datum $(4,838.06$ to $4,838.86$ feet above mean sea level). Flow in the stream ranged from 0.05 to 9.7 cubic feet per second. Annual daily mean flow for calendar year 2002 was approximately 0.35 cubic foot per second (about 226,000 gallons per day). Samples collected from the stream had low concentrations of all constituents measured. Four compounds associated with human activity (camphor, N,N-diethyl-meta-toluamide (the insect repellent DEET), tributylphosphate, and methylsalicylate) were detected in the stream samples; however, concentrations were less than detection levels. Stream samples collected in April and September and analyzed for fecal coliform bacteria had densities of 76 and 110 colonies per 100 milliliters of water, respectively. No violations of water-quality standards were noted for any constituent measured in the stream samples.

Seven shallow ground-water wells were installed near a natural area in the center of the campground. Ground-water levels measured periodically in these wells and in two existing shallow piezometers generally were highest in the spring and lowest in the fall. Water temperature, $\mathrm{pH}$, and specific conductance were measured in samples collected from the shallow wells in April and September 2002. Measured pH values were consistently lowest in samples from two wells on the west side of the natural area and highest in samples from the well located near the center of the natural area. Specific-conductance values measured in samples from wells on the east side of the natural area were lower than those measured in samples from the other wells. Specific-conductance values measured in samples from two wells on the west side and from one well near the center of the natural area generally were two to three times higher than the specific-conductance values measured in samples from wells on the east side of the natural area.

Samples for fecal coliform bacteria were collected from six wells on September 11, 2002. The fecal coliform densities in samples from most of the wells were less than or equal to 8 colonies per 100 milliliters. Samples from two of the three wells on the west side of the natural area had coliform densities of 16 and 480 colonies per 100 milliliters.

Other ground-water samples collected on September 11 and September 24 were analyzed with a spectrophotometer in the U.S. Geological Survey (USGS) North Carolina District Office for nitrate concentrations only. From the samples collected on September 11, estimated nitrate concentrations of 1 milligram per liter or less were detected in three wells, two on the west side and one on the east side of the natural area. Nitrate was not detected with a spectrophotometer in any of the ground-water samples collected on September 24. Indicator test strips also were used in the field to screen for nitrate and nitrite in ground-water samples collected on September 24. Nitrate was detected by test strips in one well on the west side of the natural area, with estimated concentrations of 1 milligram per liter or less indicated. Nitrite was not detected by the test strips in samples collected from any of the wells. 


\section{Surface- and Ground-Water Monitoring and Mapping of the Blue Ridge Parkway Mt. Pisgah Campground, N.C., 2002}

\section{Introduction}

The National Park Service (NPS) manages and maintains all areas within the boundaries of the Blue Ridge Parkway. The NPS operates a seasonal campground in the mountains of North Carolina that is located near Mt. Pisgah within the boundaries of the Blue Ridge Parkway (fig. 1). NPS managers are concerned that the Mt. Pisgah campground and nearby Pisgah Inn Lodge may potentially affect the quality of water in a small wetland that lies within a natural area located in the center of the campground (fig. 2). Little is known about the existing hydrologic and water-quality conditions of the small natural area at the Mt. Pisgah campground. Improved knowledge of the basic hydrology in the natural area was needed before determinations could be made pertaining to the possible effects resulting from the operation of the surrounding campground and other nearby facilities.

\section{Purpose and Scope}

In 2002, the USGS, in cooperation with the NPS, conducted a 1-year study to gain a better understanding of the hydrology within the Mt. Pisgah campground. The focus of the study was on the natural area located in the center of the campground. In an effort to define basic hydrologic conditions, surface- and ground-water data were collected in the study area from late 2001 to early 2003; however, discussions in this report are limited to data collected during calendar year 2002. Data collected before and after calendar year 2002 are published in USGS Annual Data Reports for North Carolina for water years 2002 and 2003 (Ragland and others, 2004a, 2004b; Howe and others, 2003 [published annually]). As part of this study, a map of the campground area was generated using global positioning system (GPS) surveying equipment. The general extent of the natural area, structures, and other features were mapped as a part of this effort (fig. 3).

Water-levels were monitored continuously in a small stream that carries all surface-water drainage from the campground area (fig. 2). Periodic measurements of streamflow were made at this stream site to develop a stage/discharge relation and thereby quantify surface-water drainage from the campground area. Water-quality samples were collected from the stream twice during the study. Ground-water levels were measured periodically in seven shallow wells and two piezometers in the study area (fig. 2). Field measurements of $\mathrm{pH}$, specific conductance, and water temperature were obtained from ground-water samples collected from the seven shallow wells.

Although beyond the original scope of this study, additional water samples were collected from the stream and six of the shallow wells (wells 2-7) in September 2002 for analysis of fecal coliform bacteria and nitrate. The additional samples that were analyzed for fecal coliform were collected on September 11, and samples analyzed for nitrate concentrations only were collected on September 11 and September 24. The additional samples collected for nitrate were analyzed with a spectrophotometer in the USGS North Carolina District Office. Indicator test strips also were used in the field to screen for nitrate and nitrite in samples collected on September 24. Unlike the analytical results reported for stream samples by the USGS National Water Quality Laboratory (NWQL) for this study, nitrate and nitrite concentrations derived by spectrophotometer analysis performed in the USGS North Carolina District Office and indicator test strips used in the field are considered to be more qualitative than quantitative. As a result, nitrate and nitrite concentrations that were determined with a spectrophotometer in the USGS North Carolina District Office or with indicator test strips are presented in this report as estimates.

\section{Description of Study Area}

Mt. Pisgah lies within the NPS boundaries along the Blue Ridge Parkway in Buncombe and Haywood Counties of North Carolina (fig. 1). Near Mt. Pisgah, at Blue Ridge Parkway mile mark 408.6, the Pisgah Inn Lodge, a motel and restaurant for Parkway visitors, is operated under a concessions contract with the NPS (fig. 2). A number of related facilities, including a camp store, gift shop, gas station, employee dormitories, and paved parking areas, are located at the Pisgah Inn (National Park Service, written commun., March 5, 2003). On the west side of the Blue Ridge Parkway near the Pisgah Inn, at mile mark 408.8, the NPS also operates a small seasonal campground. Each year the campground at Mt. Pisgah opens around the first of May and closes at the end of October (National Park Service, oral commun., January 2004).

The Mt. Pisgah campground is located in a bowl-shaped valley that slopes downward to the northwest and has 70 tent campsites and 67 recreational vehicle (RV) permitted campsites (figs. 2, 3). Several comfort stations with cold running water, bathrooms, and utility sinks are located in the campground. An RV sanitary dump station is located on the southwest side of the campground area. Access roads within the campground area are paved and roughly form the shape of a horseshoe (fig. 2). Elevation changes of more than 50 feet ( $\mathrm{ft}$ ) occur along the horseshoe-shaped layout of the access roads; the open end of the horseshoe is the lowest in elevation and the rounded end is the highest. There are three loop roads that provide access to camping areas- Loop A, Loop B, and Loop C (fig. 2). 


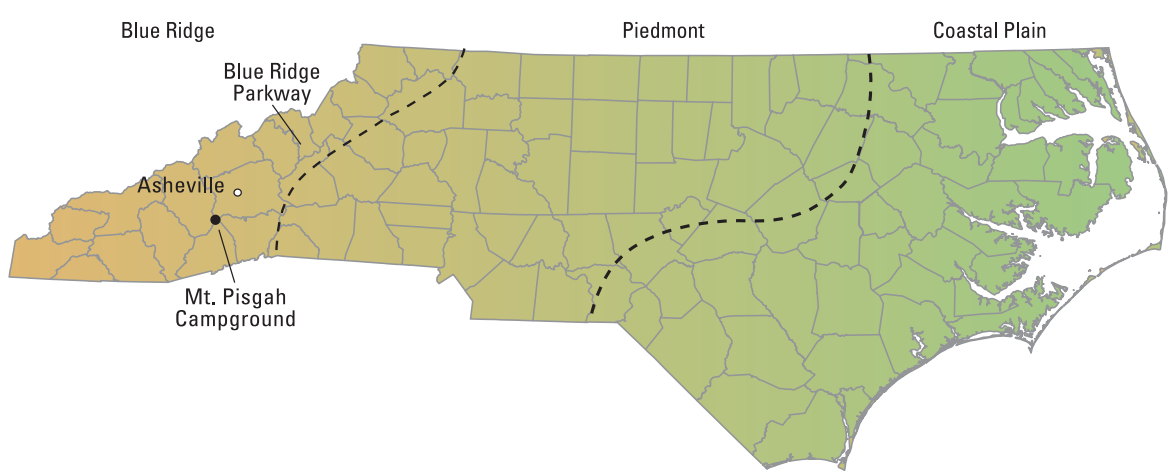

LOCATIONS OF MT. PISGAH CAMPGROUND, BLUE RIDGE PARKWAY, AND PHYSIOGRAPHIC PROVINCES IN NORTH CAROLINA

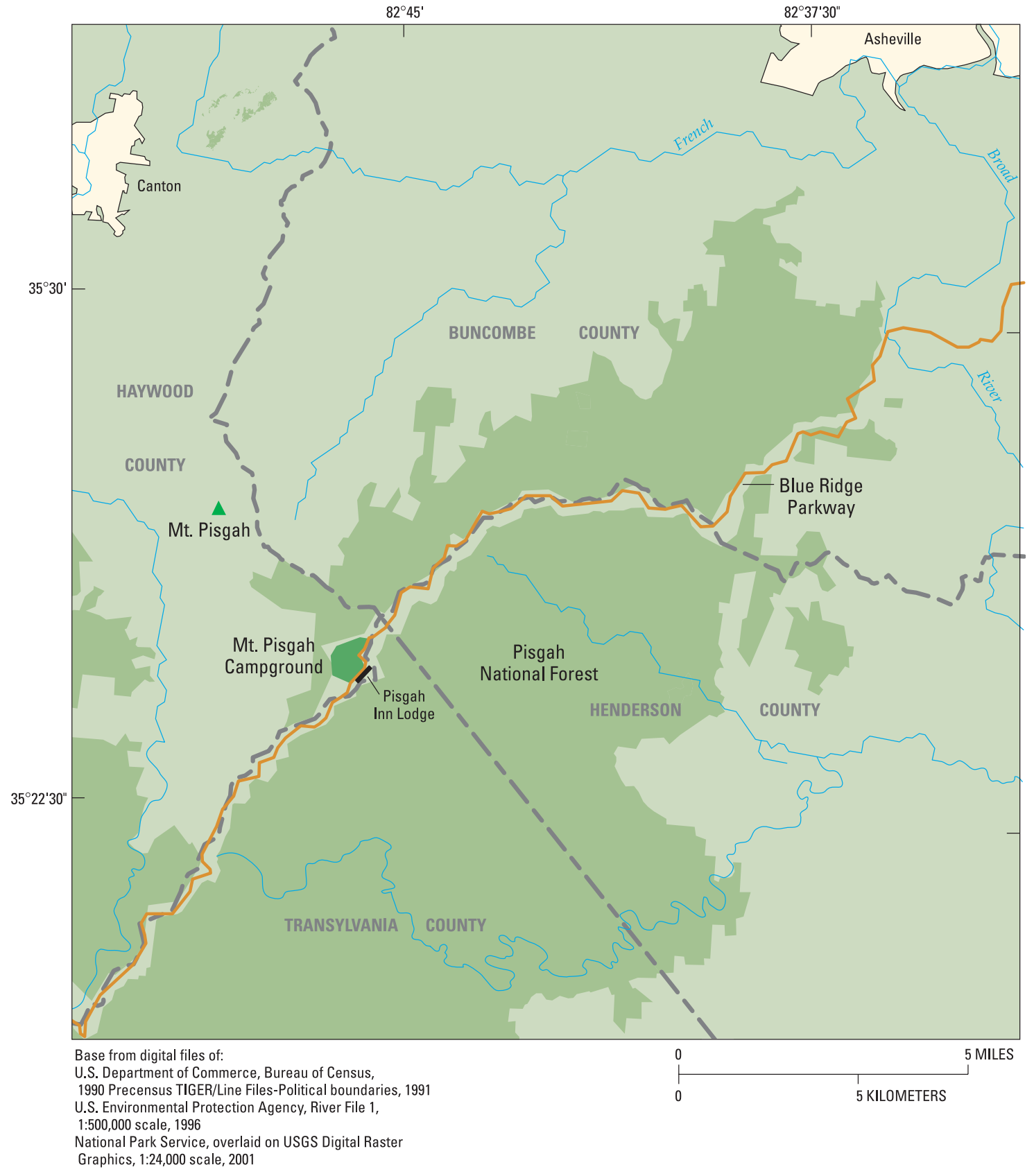

Figure 1. Location of the Mt. Pisgah campground in Haywood County, North Carolina. 


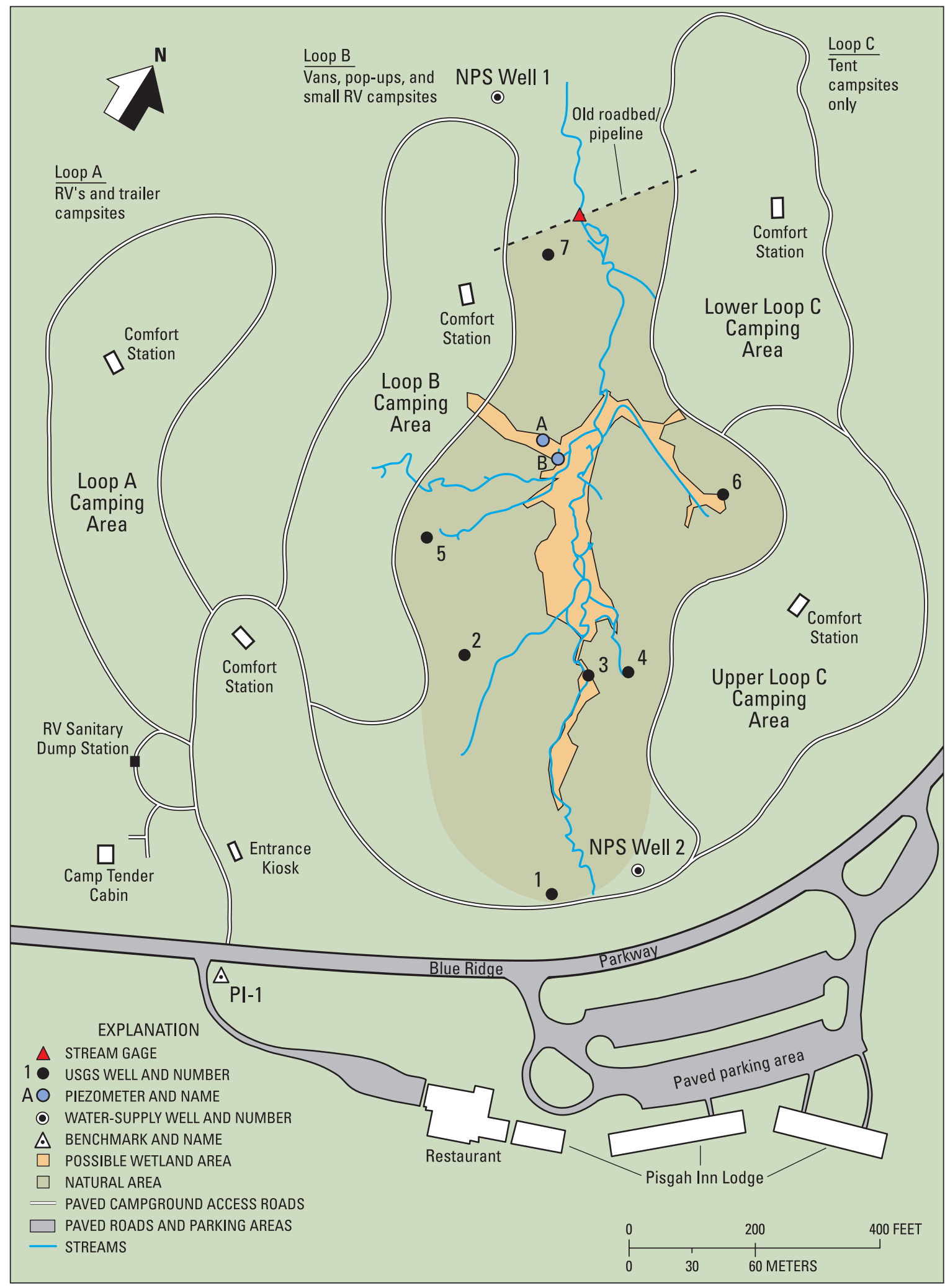

Base from:

Mt. Pisgah Developed Area Utilities Upgrade Plan,

U.S. National Park Service

Figure 2. Selected features and data-collection sites at the Mt. Pisgah campground, Haywood County, North Carolina. 


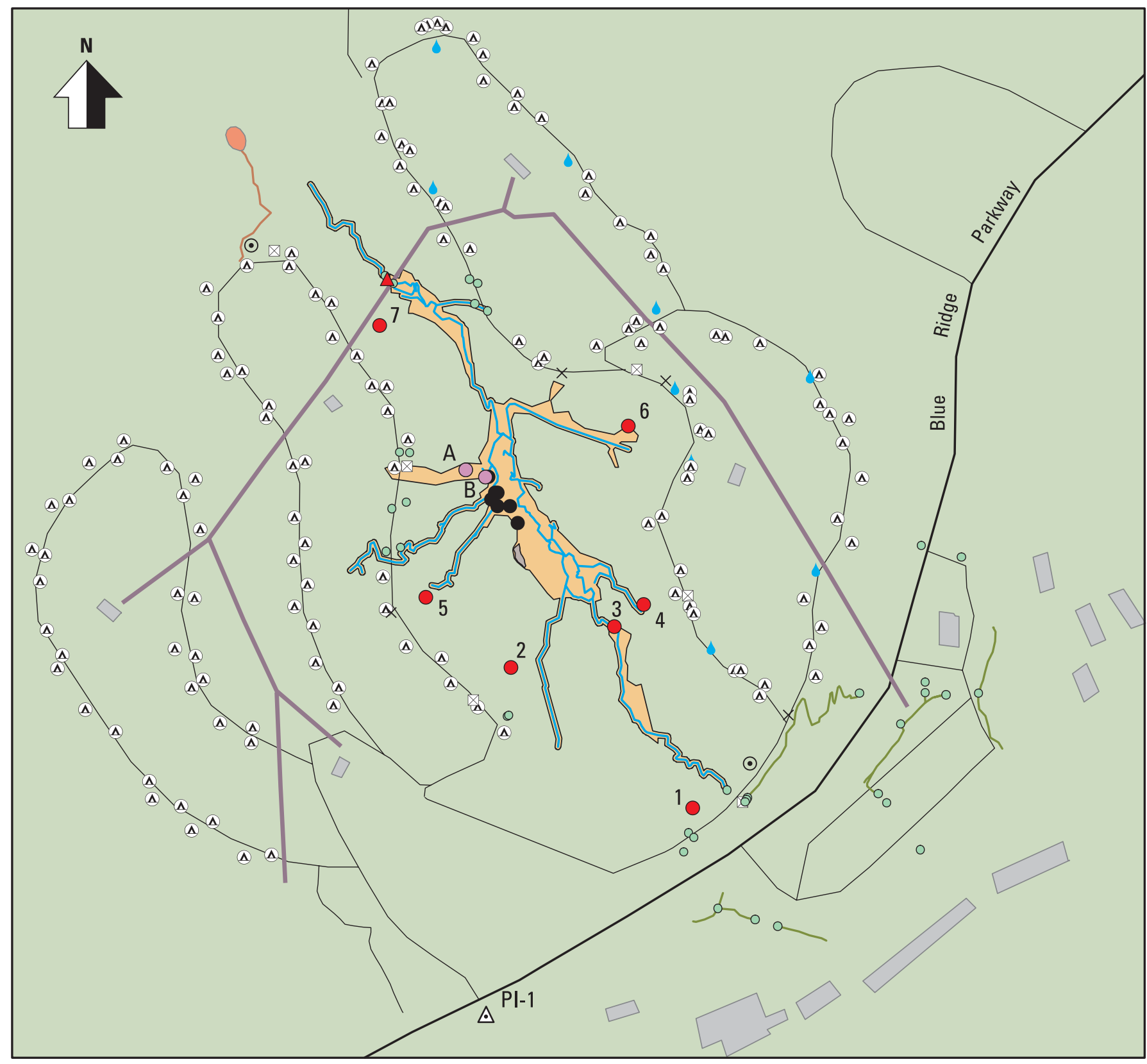

Base from:

Mt. Pisgah Developed Area Utilities Upgrade Plan, U.S. National Park Service

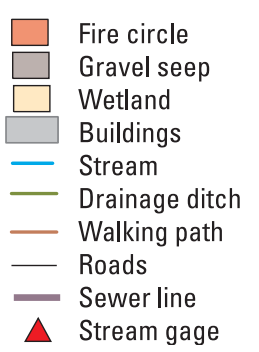

\section{EXPLANATION}

10 USGS well and number

$\mathrm{A} \bigcirc$ Piezometer and name

Other Piezometer

$\odot$ NPS supply wells

○ Culverts

Water pump

(A) Campsites

$\triangle$ Survey reference mark

$X$ Survey PK nail

$\triangle$ NC Geodetic Survey benchmark

Figure 3. Mt. Pisgah campground area map produced by a global positioning system survey in January 2002. 


\section{Surface- and Ground-Water Monitoring and Mapping of the Blue Ridge Parkway Mt. Pisgah Campground, N.C., 2002}

In the center of the campground, between Loops B and C, is a low-lying natural area that occupies about 10.5 acres. This valley floor area is covered extensively in rhododendron and other vegetation. These plants form very dense undergrowth throughout much of the natural area. An approximately 2 -acre wetland lies within this heavily vegetated area.

The low-lying natural area in the center of the campground is intermittently wet, and the ground surface is irregular with undulations of a few feet in some areas. The area is encircled on three sides by paved access roads and bounded on the downstream side by an old roadbed that connects Loops B and C near the northern end of the campground (fig. 2). A culvert underneath the old roadbed conveys surface-water drainage from the natural area. A footpath, power lines, and an iron pipeline follow the course of the old roadbed.

Surface water in the natural area generally flows from the southeast to the northwest. Several very small streams originate in and meander through the natural area. Some of these small streams are less than $1 \mathrm{ft}$ wide. During precipitation events, the natural area receives runoff from most of the campground area. Some stormwater runoff from paved surfaces along the Blue Ridge Parkway near the Pisgah Inn Lodge flows into the natural area through several culverts and other drainage structures. Wastewater from the Pisgah Inn Lodge and campground comfort stations flows through a wastewater pipeline system to a treatment facility that is located about 1,200 ft north of the lower Loop C. Two water-supply wells in the campground area serve the Pisgah Inn Lodge, campground, comfort stations, and related facilities (NPS wells 1 and 2, fig. 2). Well records indicate that NPS well 1 was drilled to a depth of $185 \mathrm{ft}$ and NPS well 2 was drilled to a depth of $400 \mathrm{ft}$ below land surface. Both of these bedrock wells are cased through the shallow ground-water system.

\section{Acknowledgments}

The author wishes to acknowledge the assistance of many National Park Service personnel who provided site access and information throughout the duration of the study. Much appreciation is expressed to Gary Francis of the North Carolina Department of Environment and Natural Resources Laboratory in Asheville, N.C., for his assistance in the analysis of bacteria samples collected during this study. The contributions of USGS employees, Bentley Walton, Mike Penley, Gene Barker, and Michelle Cienek, who collected much of the field data necessary to complete this investigation, are also appreciated.

\section{Methods}

Surface- and ground-water data were collected and a map of the campground area was produced during the study. The methods used to collect stage, streamflow, and water-quality data from the stream draining the campground area are described in this section. In addition, procedures used to collect ground-water-level and ground-water-quality data are described. The methods used for mapping the area near the campground also are described in this section.

\section{Mapping}

Using GPS equipment, field surveys were conducted one time (January 2002) during the study period to locate hydrologic and other features in the campground area. Manmade features, including roads, comfort stations, public water-supply wells, stormwater drainage-system components, and campsite parking areas, were located and mapped. Data-collection sites, stream channels and the general boundaries of wetland areas were included in the hydrologic features that were mapped (fig. 3).

Field surveys were conducted by using a portable backpack style GPS unit to collect satellite positioning data for each feature. Wet soils and(or) changes in vegetation were used to identify and map wetland areas. Extremely dense vegetation limited access and prevented complete mapping of the entire natural area. As a result, wetland areas, stream channels, and other features may be more extensive than indicated on the map in figure 3. Features, such as roads, pipelines, and drainage ditches, were mapped only near the study area. Truncation of these types of features in figure 3 may indicate where GPS field survey and mapping efforts ended. Surveyed features were verified against areal photography for accuracy. Adjustments were made where needed to match locations in the aerial photography. All GPS surveys were based on North American Datum of 1983 (NAD83) data with a minimum reception of three satellites. Horizontal accuracy tolerances of the GPS unit used were within $10 \mathrm{ft}$. 


\section{Streamwater Levels and Streamflow}

Water level (stage) and flow (discharge) in the stream draining the campground area were monitored from January 1 to December 31, 2002. An old access road that connects Loops B and C partially impounds surface-water drainage from the natural area (fig. 2). Immediately upstream from the old access road, several small streams converge into a single channel before flowing through two corrugated metal pipe (CMP) culverts that pass beneath the old roadbed (fig. 4). On the downstream side of the culvert, water empties into a small natural pool before flowing into a single, well-defined channel.

A USGS streamgaging station was constructed at the downstream side of the culvert (fig. 5) to monitor stage fluctuations in the stream flowing from the natural area in the center of the campground. This stream site was identified as Unnamed Tributary to Pisgah Creek at Flat Laurel Gap, N.C., with USGS station number 0345638607. A steel enamel staff gage was installed in the stream at the downstream side of the culvert. Stage in the stream was monitored by a pressure transducer that was referenced to the staff gage and recorded by instrumentation housed in the gage shelter. Stage data were recorded at 15-minute intervals using an arbitrary gage datum. Recorded stage readings and the staff gage in the stream were set so that a stage of $0.00 \mathrm{ft}$ in gage datum represented a corresponding water-surface elevation of $4,836.97 \mathrm{ft}$ above mean sea level (referenced in this report to National Geodetic Vertical Datum of 1929 [NGVD29]). The mean sea level elevation of gage datum was determined by level surveys based on a nearby North Carolina Geodetic Survey benchmark (PI-1 1994).

Streamflow was measured periodically in the stream channel near the gaging station. All streamflow measurements were made with a standard current meter using established USGS techniques and procedures (Rantz and others, 1982). A stage/discharge relation, based on measurements of streamflow, was developed for the site.

\section{Streamwater Quality}

Two sets of water-quality samples were collected from the stream and analyzed for major ions, nutrients, wastewater compounds, fecal coliform bacteria, and selected metals. These samples were collected strategically during different seasons of the year so that analytical results could provide indications of the presence or absence of human influence on the quality of water flowing from the campground area. The first set of samples was collected from the stream on April 23, 2002, at a time when the campground was inactive and had been closed for about 6 months. The second set of samples was collected on September 11, 2002, at a time when the campground was open and had been in use for about $4 \frac{1}{2}$ months. An additional stream sample was collected on September 24, 2002, for analysis with a spectrophotometer for nitrate concentrations only. The sample collected on September 24 was supplemental and used for comparison to ground-water samples that were collected on the same date.

All water-quality samples taken from the stream were collected at the upstream side of the culvert. Raw or unfiltered water samples were collected in bottles by hand. For dissolved constituent analyses, water was pumped directly from the stream and filtered onsite using a peristaltic pump and an in-line cartridge filter. Water temperature, $\mathrm{pH}$, and specific conductance were measured in the field using a multiprobe instrument when samples were collected. Values of dissolved oxygen and alkalinity also were determined in the field during sample collection.

Most water-quality samples collected from the stream were analyzed at the NWQL in Denver, Colo. In addition to major ions, nutrients, and selected metals, stream samples were analyzed at the NWQL for 67 compounds typically found in domestic and industrial wastewater. These compounds included surfactants, food additives, fragrances, antioxidants, flame retardants, plasticizers, industrial solvents, disinfectants, fecal sterols, polycyclic aromatic hydrocarbons, and high-use domestic pesticides (Zaugg and others, 2002). Samples collected for fecal coliform bacteria were analyzed by the North Carolina Department of Environment and Natural Resources laboratory in Asheville, N.C. Supplemental stream samples collected on September 11 and September 24 were analyzed for nitrate concentrations only using a spectrophotometer at the USGS District Office in Raleigh, N.C. Indicator test strips also were used in the field on September 24 to screen for nitrate and nitrite in the stream. In this report, all nitrate and nitrite values determined with a spectrophotometer in the USGS North Carolina District Office or with indicator test strips are considered to be estimates.

\section{Ground-Water Levels}

Periodic ground-water levels were measured in seven newly installed wells and two existing piezometers in the study area. The seven wells were installed at shallow depths near or within the natural area to measure water levels and allow the collection of field water-quality data for this study. Six of these wells were installed near the perimeter of the natural area and one (well 3) was installed near the center of the area (fig. 2). All seven of these wells were constructed of polyvinyl chloride (PVC) pipe, 1.5 inches in diameter, with a slotted PVC well screen and solid PVC well point attached to the bottom. Each well was installed 

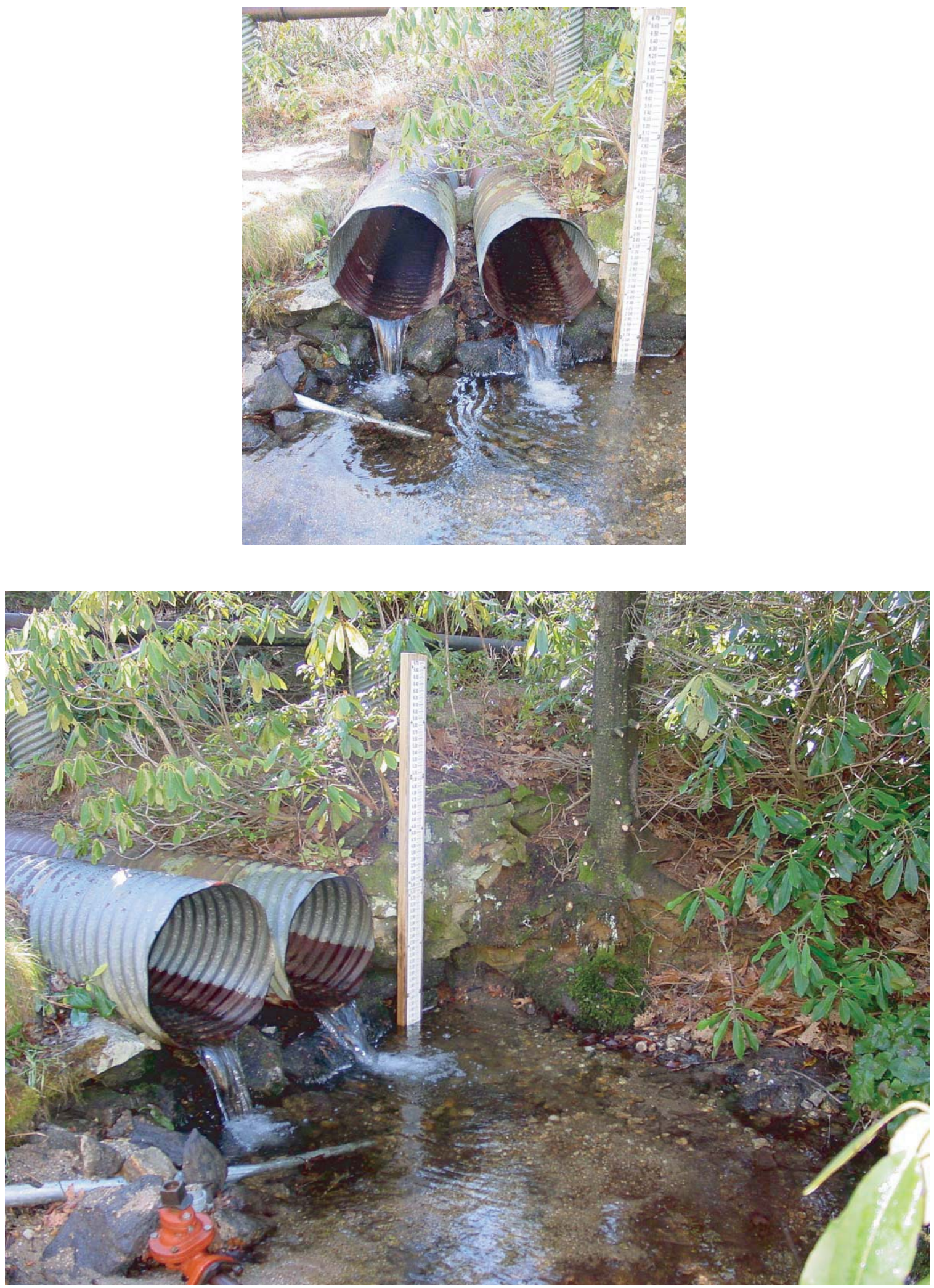

Figure 4. The downstream side of the double corrugated metal pipe (CMP) culvert where the U.S. Geological Survey gaging station was located at the Mt. Pisgah campground. 


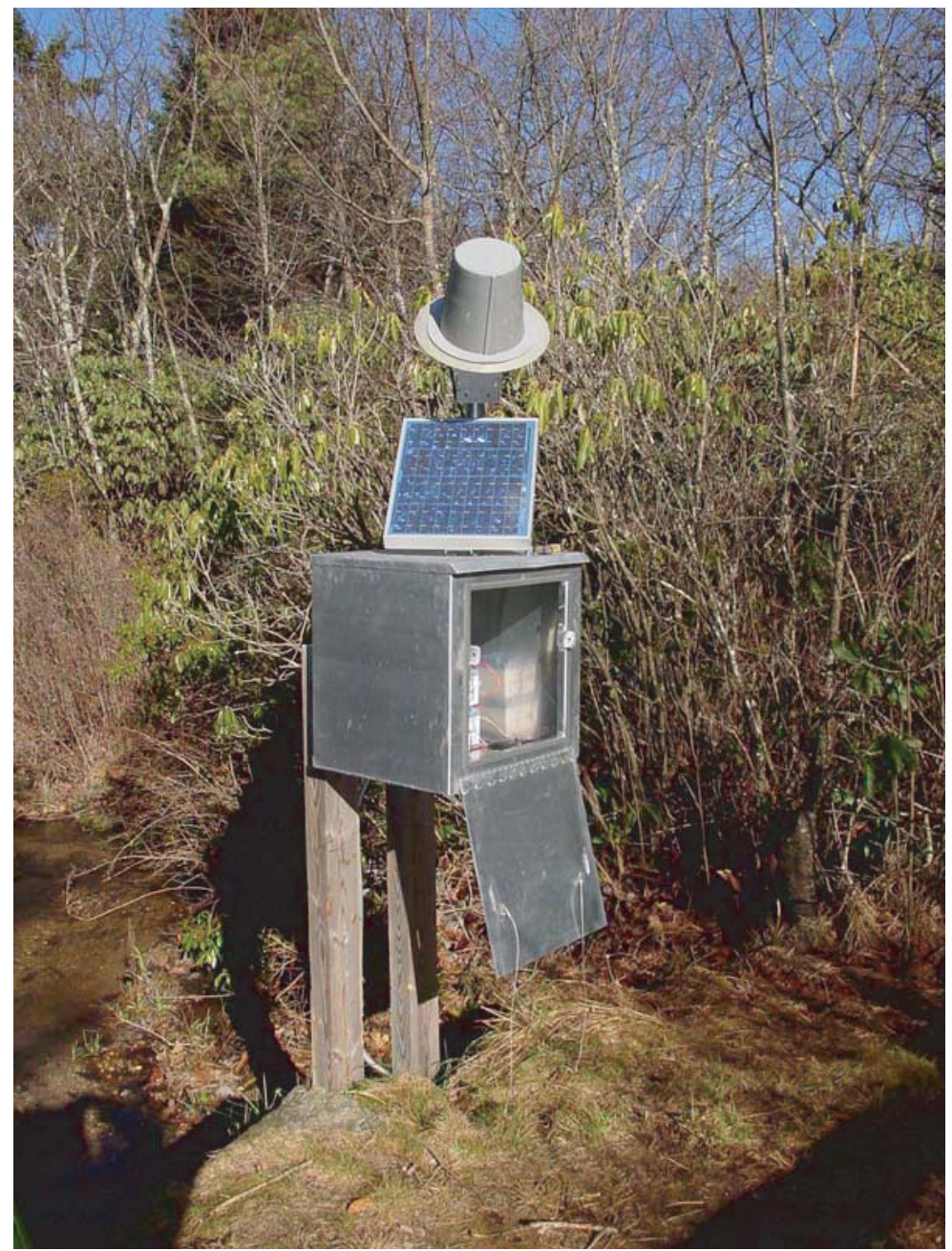

Figure 5. The U.S. Geological Survey gaging station that was built to monitor water levels in the stream flowing from the natural area in the center of the Mt. Pisgah campground.

by hand-augering a borehole 3 inches in diameter into the ground. The deepest of these wells was installed to a depth of about $6.5 \mathrm{ft}$ below land surface, and the most shallow well was installed to a depth of about $2 \mathrm{ft}$ below land surface. The annular space around the screen of each newly constructed well was backfilled with fine sand. The two existing piezometers had been installed in a grassy area in the interior part of the natural area (A and B, fig. 2) as part of an earlier study. These piezometers consisted of $3 / 4$-inch PVC pipe installed to depths of about $1 \mathrm{ft}$ below land surface.

Water-level measurements in each well and piezometer were made by using a steel or electric tape from a measuring point marked on the top of the well casing. Field surveys, based on a North Carolina Geodetic Survey benchmark (PI-1 1994), were conducted during the study to determine the measuring point elevation of wells 1-7 and piezometers A and B. Several other existing piezometers were located and mapped in the natural area near piezometers A and B (fig. 3). Water levels were not measured in any of these additional piezometers. Two deep water-supply wells were located in the campground area (NPS wells 1 and 2, fig. 2). Water levels were not measured in either of these bedrock wells during the study.

\section{Ground-Water Quality}

Field measurements of water temperature, $\mathrm{pH}$, and specific conductance were made in samples collected from the shallow wells in April and September 2002. To verify water-quality field data collected on April 23, supplemental field measurements were 
made in samples from some wells on April 24, 2002. Likewise, in an effort to better define representative conditions, two separate samples were collected from wells 2-7 on September 24, 2002. Samples were collected and water-quality field measurements were made on September 24 before and after each well was purged, with the first set of measurements made from undisturbed water in the well. The second set of field measurements from September 24 were made after pumping each well dry and subsequently allowing water levels to recover inside the wells.

Water temperature, $\mathrm{pH}$, and specific conductance were measured in the field by using a multiprobe instrument. All field measurements were made after removing a sample of water from each well by using a peristaltic pump. Pump tubing was completely replaced or was rinsed with distilled and native water before and after obtaining samples from each well.

Supplemental water-quality samples were collected from six wells (wells 2-7) in September 2002 and analyzed for fecal coliform bacteria and nitrate. Samples for fecal coliform bacteria were collected from the wells on September 11 and analyzed by the North Carolina Department of Environment and Natural Resources laboratory in Asheville. Samples collected from the wells on September 11 and September 24 were analyzed only for nitrate concentrations with a spectrophotometer at the USGS District Office in Raleigh. Indicator test strips also were used in the field on September 24 to screen for nitrate and nitrite in samples collected from the wells. In this report, all nitrate and nitrite values determined with a spectrophotometer in the USGS North Carolina District Office or with indicator test strips are considered to be estimates.

Most wells were installed at very shallow depths, thus, dry climatic conditions during the investigation resulted in limited volumes of water available for sample collection in some of the wells. For example, well 1 (fig. 2) was nearly dry on June 13 and was completely dry on September 11 and September 24. As a result, limited water-level and water-quality data were obtained from well 1 . Water samples that were collected from nearly dry wells were often heavily laden with sediment. Hence, some of the waterquality data determined from these samples may not be considered as representative of naturally occurring ground-water conditions.

\section{Results}

Surface- and ground-water data collected during this study are summarized below. Stage and streamflow data collected for the stream draining the campground area are summarized. The analytical results of water-quality samples collected from this stream site also are discussed. Water-level and water-quality data collected from shallow wells and piezometers located within the campground area also are summarized in this section.

\section{Stream Stage and Streamflow}

Continuously recorded stage in the stream ranged from 1.09 to $1.89 \mathrm{ft}$ above gage datum $(4,838.06$ to $4,838.86 \mathrm{ft}$ above mean sea level) during the 2002 calendar year. Periodic measurements of streamflow (discharge) ranged in stage from 1.11 to $1.66 \mathrm{ft}$ and in discharge from 0.07 to 4.71 cubic feet per second $\left(\mathrm{ft}^{3} / \mathrm{s}\right)$. A stage/discharge relation was developed using these streamflow measurements, and corresponding discharge values were calculated for each stage value recorded by the gage. A hydrograph of mean daily discharges for calendar year 2002 is shown in figure 6 as calculated for each day of the period of study (table 1). An additional table containing daily maximum, minimum, and mean discharge values also is presented in the appendix (table A1).

Based on recorded stage data for calendar year 2002, streamflow from the natural area ranged from 0.05 to $9.7 \mathrm{ft}^{3} / \mathrm{s}$. The annual daily mean flow for the year was approximately $0.35 \mathrm{ft}^{3} / \mathrm{s}$ (about 226,000 gallons per day). The instantaneous peak stage $(1.89 \mathrm{ft})$ and discharge $\left(9.7 \mathrm{ft}^{3} / \mathrm{s}\right)$ occurred on September 26,2002 , and the instantaneous minimum flow $\left(0.05 \mathrm{ft}^{3} / \mathrm{s}\right)$ occurred on August 23 and September 7, 9, 10, and 11, 2002. The highest monthly mean flow occurred during December 2002, and the lowest monthly mean flow occurred during August 2002. 


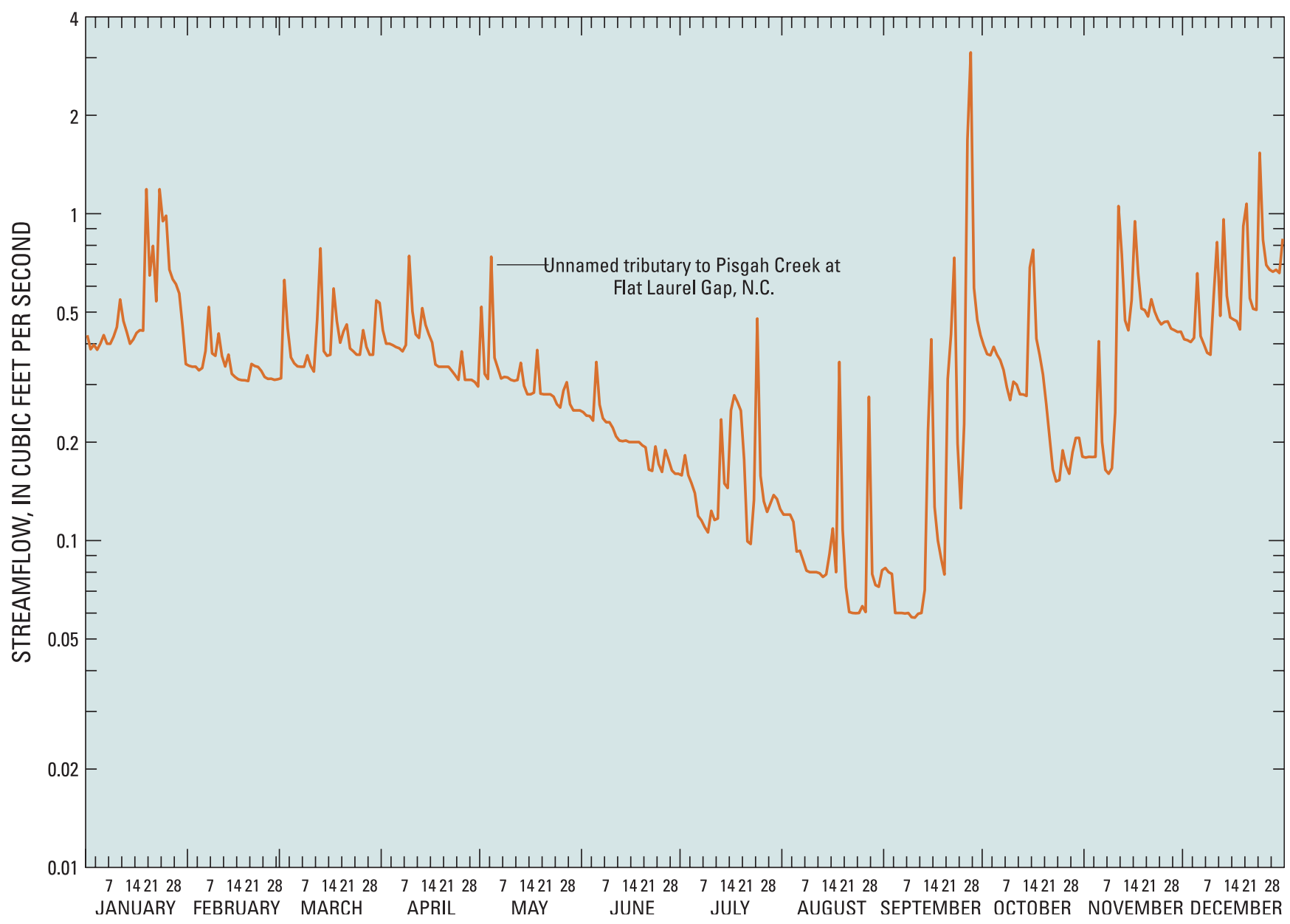

Figure 6. Daily mean steamflow values at unnamed tributary to Pisgah Creek at Flat Laurel Gap at the Mt. Pisgah campground.

\section{Streamwater Quality}

Analytical results of water-quality samples collected from the stream in April and September indicate that surface water flowing from the natural area in the center of the campground had low concentrations of the constituents measured, similar to those reported in undisturbed streams in the Blue Ridge Province (Simmons and Heath, 1982). USGS laboratory analytical results of the stream samples are shown in table 2. Measurements of $\mathrm{pH}$ made in the stream during sample collection in April and September ranged from 5.5 to 6.3 , and specific conductance values ranged from 6 to 14 microsiemens per centimeter at $25^{\circ} \mathrm{C}(\mu \mathrm{S} / \mathrm{cm}$; table 3). Four compounds associated with human activity (camphor, N,N-diethyl-meta-toluamide (DEET), tributylphosphate, and methylsalicylate) were detected in the stream samples; however, concentrations were less than detection levels and analytical results for these compounds are reported as estimates (table 2). Camphor was detected in the sample collected in April following a period when the campground had been closed for about 6 months. The presence of camphor in the April sample suggests that inadvertent contamination occurred during sample collection or analysis. The remaining three compounds were detected in the sample collected in September after the campground had been in use for about $4 \frac{1}{2}$ months. Further sampling is necessary to determine whether these compounds are consistently detected in the stream. Samples collected from the stream in April and September and analyzed for fecal coliform bacteria had densities of 76 and 110 colonies per 100 milliliters (col/100 mL) of water, respectively. Nitrate and nitrite concentrations were not detected by spectrophotometer analysis performed in the USGS North Carolina District Office or by indicator test strips in samples collected from the stream in September (table 3). No violations of water-quality standards for any constituent measured were noted in the stream samples. 
Table 1. Daily mean discharge recorded during calendar year 2002 at Mt. Pisgah campground, Haywood County, North Carolina.

[e, estimated; MAX, maximum; MIN, minimum; CFSM, cubic feet per second per square mile; IN., inches]

\begin{tabular}{|c|c|c|c|c|c|c|c|c|c|c|c|c|}
\hline Day & JAN & FEB & MAR & APR & MAY & JUNE & JULY & AUG & SEPT & OCT & NOV & DEC \\
\hline 1 & 0.42 & 0.34 & 0.31 & $\mathrm{e} 0.44$ & 0.52 & 0.25 & 0.16 & 0.12 & 0.08 & 0.39 & 0.18 & 0.41 \\
\hline 2 & 0.38 & 0.34 & 0.63 & 0.40 & 0.32 & 0.24 & 0.18 & 0.12 & 0.08 & 0.37 & 0.18 & 0.41 \\
\hline 3 & 0.40 & 0.34 & 0.45 & 0.40 & 0.31 & 0.24 & 0.16 & 0.12 & 0.08 & 0.37 & 0.18 & 0.40 \\
\hline 4 & 0.38 & 0.33 & 0.36 & 0.40 & 0.74 & 0.23 & 0.15 & 0.11 & 0.06 & 0.39 & 0.18 & 0.42 \\
\hline 5 & 0.40 & 0.34 & 0.35 & 0.39 & 0.36 & 0.35 & 0.14 & 0.09 & 0.06 & 0.37 & 0.41 & 0.66 \\
\hline 6 & 0.42 & 0.38 & 0.34 & 0.39 & 0.34 & 0.26 & 0.12 & 0.09 & 0.06 & 0.36 & 0.20 & 0.42 \\
\hline 7 & 0.40 & 0.52 & 0.34 & 0.38 & 0.31 & 0.24 & 0.12 & 0.09 & 0.06 & 0.33 & 0.16 & 0.40 \\
\hline 8 & 0.40 & 0.37 & 0.34 & 0.40 & 0.32 & 0.23 & 0.11 & 0.08 & 0.06 & 0.29 & 0.16 & 0.38 \\
\hline 9 & 0.42 & 0.37 & 0.37 & 0.74 & 0.32 & 0.23 & 0.11 & 0.08 & 0.06 & 0.27 & 0.17 & 0.37 \\
\hline 10 & 0.45 & 0.43 & 0.34 & 0.50 & 0.31 & 0.22 & 0.12 & 0.08 & 0.06 & 0.31 & 0.25 & 0.56 \\
\hline 11 & 0.55 & 0.37 & 0.33 & 0.43 & 0.31 & 0.21 & 0.12 & 0.08 & 0.06 & 0.30 & 1.1 & 0.82 \\
\hline 12 & 0.47 & 0.34 & 0.47 & 0.42 & 0.31 & 0.20 & 0.12 & 0.08 & 0.06 & 0.28 & 0.75 & 0.49 \\
\hline 13 & 0.43 & 0.37 & 0.78 & 0.51 & 0.35 & 0.20 & 0.23 & 0.08 & 0.07 & 0.28 & 0.47 & 0.96 \\
\hline 14 & 0.40 & 0.32 & 0.38 & 0.46 & 0.30 & 0.20 & 0.15 & 0.08 & 0.22 & 0.28 & 0.44 & 0.56 \\
\hline 15 & 0.41 & 0.32 & 0.37 & 0.43 & 0.28 & 0.20 & 0.14 & 0.09 & 0.41 & 0.68 & 0.54 & 0.48 \\
\hline 16 & 0.43 & 0.31 & $\mathrm{e} 0.37$ & 0.40 & 0.28 & 0.20 & 0.25 & 0.11 & 0.13 & 0.78 & 0.95 & 0.47 \\
\hline 17 & 0.44 & 0.31 & 0.59 & 0.35 & 0.28 & 0.20 & 0.28 & 0.08 & 0.10 & 0.41 & 0.65 & 0.47 \\
\hline 18 & 0.44 & 0.31 & 0.47 & 0.34 & 0.38 & 0.20 & 0.26 & 0.35 & 0.09 & 0.37 & 0.51 & 0.44 \\
\hline 19 & 1.2 & 0.31 & 0.40 & 0.34 & 0.28 & 0.20 & 0.25 & 0.11 & 0.08 & 0.32 & 0.51 & 0.92 \\
\hline 20 & 0.65 & 0.35 & 0.44 & 0.34 & 0.28 & 0.19 & 0.18 & 0.07 & 0.31 & 0.26 & 0.48 & 1.1 \\
\hline 21 & 0.80 & 0.34 & 0.46 & 0.34 & 0.28 & 0.16 & 0.10 & 0.06 & 0.43 & 0.21 & 0.55 & 0.55 \\
\hline 22 & 0.54 & 0.34 & 0.39 & 0.33 & 0.28 & 0.16 & 0.10 & 0.06 & 0.73 & 0.17 & 0.50 & 0.51 \\
\hline 23 & 1.2 & 0.33 & 0.38 & 0.32 & 0.28 & 0.19 & 0.13 & 0.06 & 0.20 & 0.15 & 0.47 & 0.51 \\
\hline 24 & 0.95 & 0.32 & 0.37 & 0.31 & 0.26 & 0.17 & 0.48 & 0.06 & 0.13 & 0.15 & 0.46 & 1.5 \\
\hline 25 & 0.99 & 0.31 & 0.37 & 0.38 & 0.26 & 0.16 & 0.16 & 0.06 & 0.23 & 0.19 & 0.47 & 0.83 \\
\hline 26 & 0.67 & 0.31 & $\mathrm{e} 0.44$ & 0.31 & 0.29 & 0.19 & 0.13 & 0.06 & 1.7 & 0.17 & 0.47 & 0.70 \\
\hline 27 & 0.63 & 0.31 & 0.39 & 0.31 & 0.30 & 0.18 & 0.12 & 0.28 & 3.1 & 0.16 & 0.44 & 0.67 \\
\hline 28 & 0.61 & 0.31 & 0.37 & 0.31 & 0.26 & 0.16 & 0.13 & 0.08 & 0.59 & 0.19 & 0.44 & 0.66 \\
\hline 29 & 0.57 & --- & 0.37 & 0.31 & 0.25 & 0.16 & 0.14 & 0.07 & 0.47 & 0.21 & 0.43 & 0.67 \\
\hline 30 & 0.45 & --- & 0.54 & 0.30 & 0.25 & 0.16 & 0.13 & 0.07 & 0.42 & 0.21 & 0.44 & 0.66 \\
\hline 31 & 0.35 & --- & 0.53 & --- & 0.25 & --- & 0.12 & 0.08 & --- & 0.18 & --- & 0.84 \\
\hline TOTAL & 17.25 & 9.64 & 13.04 & 11.68 & 9.86 & 6.18 & 5.09 & 3.05 & 10.19 & 9.40 & 13.14 & 19.24 \\
\hline MEAN & 0.56 & 0.34 & 0.42 & 0.39 & 0.32 & 0.21 & 0.16 & 0.098 & 0.34 & 0.30 & 0.44 & 0.62 \\
\hline MAX & 1.2 & 0.52 & 0.78 & 0.74 & 0.74 & 0.35 & 0.48 & 0.35 & 3.1 & 0.78 & 1.1 & 1.5 \\
\hline MIN & 0.35 & 0.31 & 0.31 & 0.30 & 0.25 & 0.16 & 0.10 & 0.06 & 0.06 & 0.15 & 0.16 & 0.37 \\
\hline CFSM & 7.95 & 4.92 & 6.01 & 5.56 & 4.54 & 2.94 & 2.35 & 1.41 & 4.85 & 4.33 & 6.26 & 8.87 \\
\hline IN. & 9.17 & 5.12 & 6.93 & 6.21 & 5.24 & 3.28 & 2.70 & 1.62 & 5.42 & 5.00 & 6.98 & 10.22 \\
\hline
\end{tabular}


Table 2. Water-quality data from an unnamed tributary to Pisgah Creek at Mt. Pisgah campground, Haywood County, North Carolina, April 23 and September 11, 2002.

$\left[\mathrm{ft}^{3} / \mathrm{s}\right.$, cubic feet per second; mg/L, milligrams per liter; $\mu \mathrm{S} / \mathrm{cm}$, microsiemens per centimeter at 25 degrees Celsius; ${ }^{\circ} \mathrm{C}$, degrees Celsius; ANC, acid neutralizing capacity; $\mathrm{N}$, nitrogen; $\mathrm{P}, \mathrm{phosphorus;} \mathrm{col} / 100 \mathrm{~mL}$, colonies per 100 milliliters; $\mu \mathrm{g} / \mathrm{L}$, micrograms per liter; <, less than; E, estimated value; AHTN, acetyl hexamethyl tetrahydro naphthalene; M, presence verified, but not quantified; HHCB, hexahydrohexamethyl cyclopentabenzopyran]

PERIOD OF RECORD.--April and September 2002

REMARKS.--Station operated in cooperation with the National Park Service to define baseline water quality of a small wetland in the Blue Ridge Parkway.

\begin{tabular}{|c|c|c|c|c|c|c|c|c|c|c|c|c|c|}
\hline Date & Time & $\begin{array}{c}\text { Instan- } \\
\text { taneous } \\
\text { discharge, } \\
\text { in } \mathrm{ft}^{3} / \mathrm{s} \\
(00061) \\
\end{array}$ & $\begin{array}{l}\text { Dissolved } \\
\text { oxygen, } \\
\text { in } \mathrm{mg} / \mathrm{L} \\
(00300)\end{array}$ & $\begin{array}{c}\text { Dissolved } \\
\text { oxygen, } \\
\text { percent of } \\
\text { saturation } \\
\text { (00301) }\end{array}$ & $\begin{array}{c}\mathrm{pH}, \\
\text { water, } \\
\text { unfiltered, } \\
\text { field, } \\
\text { standard units } \\
\text { (00400) } \\
\end{array}$ & $\begin{array}{c}\text { Specific } \\
\text { conduc- } \\
\text { tance, } \\
\text { water } \\
\text { unfiltered, } \\
\text { in } \mu \mathrm{S} / \mathrm{cm} \\
(00095) \\
\end{array}$ & $\begin{array}{c}\text { Temper- } \\
\text { ature, } \\
\text { water } \\
\left({ }^{\circ} \mathrm{C}\right) \\
(00010) \\
\end{array}$ & $\begin{array}{c}\text { Calcium, } \\
\text { water, } \\
\text { filtered, } \\
\text { in } \mathrm{mg} / \mathrm{L} \\
(00915) \\
\end{array}$ & $\begin{array}{l}\text { Magnesium, } \\
\text { water, } \\
\text { filtered, } \\
\text { in } \mathrm{mg} / \mathrm{L} \\
(00925)\end{array}$ & $\begin{array}{c}\text { Potassium, } \\
\text { water, } \\
\text { filtered, } \\
\text { in } \mathrm{mg} / \mathrm{L} \\
(00935)\end{array}$ & $\begin{array}{l}\text { Sodium, } \\
\text { water, } \\
\text { filtered, } \\
\text { in } \mathrm{mg} / \mathrm{L} \\
(00930) \\
\end{array}$ & $\begin{array}{l}\text { ANC, water, } \\
\text { unfiltered, fixed } \\
\text { end- point } \\
\text { titration, field, } \\
\text { in } \mathrm{mg} / \mathrm{L} \text { as } \\
\mathrm{CaCO}_{3} \\
(00410) \\
\end{array}$ & $\begin{array}{c}\text { Chloride, } \\
\text { water, } \\
\text { filtered, } \\
\text { in } \mathrm{mg} / \mathrm{L} \\
(00940) \\
\end{array}$ \\
\hline $4 / 23 / 02$ & 1155 & 0.33 & 9.0 & 77 & 6.1 & 6 & 8.2 & 0.65 & 0.317 & 0.37 & 0.64 & 3 & 0.60 \\
\hline $9 / 11 / 02$ & 1130 & .07 & 8.2 & 75 & 6.3 & 7 & 13.2 & .66 & .345 & .39 & .77 & 3 & .60 \\
\hline Date & Time & $\begin{array}{l}\text { Fluoride, } \\
\text { water, } \\
\text { filtered, } \\
\text { in } \mathrm{mg} / \mathrm{L} \\
(00950)\end{array}$ & $\begin{array}{l}\text { Silica, } \\
\text { water, } \\
\text { filtered, } \\
\text { in } \mathrm{mg} / \mathrm{L} \\
(00955)\end{array}$ & $\begin{array}{c}\text { Sulfate, } \\
\text { water, } \\
\text { filtered, } \\
\text { in } \mathrm{mg} / \mathrm{L} \\
(00945)\end{array}$ & $\begin{array}{l}\text { Ammonia plus } \\
\text { organic } \\
\text { nitrogen, } \\
\text { water, filtered, } \\
\text { in } \mathrm{mg} / \mathrm{L} \text { as N } \\
(00623)\end{array}$ & $\begin{array}{c}\text { Ammonia, } \\
\text { water, } \\
\text { filtered, } \\
\text { in } \mathrm{mg} / \mathrm{L} \text { as } \mathrm{N} \\
(00608)\end{array}$ & $\begin{array}{l}\text { Nitrite plus } \\
\text { nitrate, } \\
\text { water, } \\
\text { filtered, } \\
\text { in } \mathrm{mg} / \mathrm{L} \text { as } \mathrm{N} \\
(00631)\end{array}$ & $\begin{array}{c}\text { Nitrite, } \\
\text { water, } \\
\text { filtered, } \\
\text { in } \mathrm{mg} / \mathrm{L} \text { as } \mathrm{N} \\
(00613)\end{array}$ & $\begin{array}{l}\text { Orthophos- } \\
\text { phate, } \\
\text { water, } \\
\text { filtered, } \\
\text { in } \mathrm{mg} / \mathrm{L} \text { as } \mathrm{P} \\
(00671)\end{array}$ & $\begin{array}{l}\text { Phosphorus, } \\
\text { water, } \\
\text { unfiltered, } \\
\text { in } \mathrm{mg} / \mathrm{L} \\
(00665)\end{array}$ & $\begin{array}{l}\text { Fecal coliform, } \\
\text { M-FC MF } \\
\text { (0.45 micron) } \\
\text { method, water, } \\
\text { col/100 mL } \\
(31616)\end{array}$ & $\begin{array}{c}\text { Aluminum, } \\
\text { water, } \\
\text { filtered, } \\
\text { in } \mu \mathrm{g} / \mathrm{L} \\
(01106)\end{array}$ & $\begin{array}{l}\text { Arsenic, } \\
\text { water, } \\
\text { filtered, } \\
\text { in } \mu \mathrm{g} / \mathrm{L} \\
(01000)\end{array}$ \\
\hline $4 / 23 / 02$ & 1155 & $<0.10$ & 4.37 & 0.5 & $<0.10$ & $<0.04$ & 0.12 & $<0.008$ & $<0.02$ & $<0.06$ & 76 & 30 & $<2$ \\
\hline $9 / 11 / 02$ & 1130 & $<.10$ & 5.15 & .3 & E.06 & $<.04$ & .07 & $<.008$ & $<.02$ & $<.06$ & 110 & 20 & $<2$ \\
\hline Date & Time & $\begin{array}{l}\text { Barium, } \\
\text { water, } \\
\text { filtered, } \\
\text { in } \mu \mathrm{g} / \mathrm{L} \\
(01005)\end{array}$ & $\begin{array}{l}\text { Boron, } \\
\text { water, } \\
\text { filtered, } \\
\text { in } \mu \mathrm{g} / \mathrm{L} \\
(01020)\end{array}$ & $\begin{array}{l}\text { Cadmium, } \\
\text { water, } \\
\text { filtered, } \\
\text { in } \mu \mathrm{g} / \mathrm{L} \\
(01025)\end{array}$ & $\begin{array}{l}\text { Chromium, } \\
\text { water, } \\
\text { filtered, } \\
\text { in } \mu \mathrm{g} / \mathrm{L} \\
(01030)\end{array}$ & $\begin{array}{l}\text { Cobalt, } \\
\text { water, } \\
\text { filtered, } \\
\text { in } \mu \mathrm{g} / \mathrm{L} \\
(01035)\end{array}$ & $\begin{array}{l}\text { Copper, } \\
\text { water, } \\
\text { filtered, } \\
\text { in } \mu \mathrm{g} / \mathrm{L} \\
(01040)\end{array}$ & $\begin{array}{c}\text { Iron, } \\
\text { water, } \\
\text { filtered, } \\
\text { in } \mu \mathrm{g} / \mathrm{L} \\
(01046)\end{array}$ & $\begin{array}{c}\text { Lead, } \\
\text { water, } \\
\text { filtered, } \\
\text { in } \mu \mathrm{g} / \mathrm{L} \\
(01049)\end{array}$ & $\begin{array}{c}\text { Manganese, } \\
\text { water, } \\
\text { filtered, } \\
\text { in } \mu \mathrm{g} / \mathrm{L} \\
(01056)\end{array}$ & $\begin{array}{l}\text { Mercury, } \\
\text { water, } \\
\text { filtered, } \\
\text { in } \mu \mathrm{g} / \mathrm{L} \\
(71890)\end{array}$ & $\begin{array}{l}\text { Molybdenum, } \\
\text { water, } \\
\text { filtered, } \\
\text { in } \mu \mathrm{g} / \mathrm{L} \\
(01060)\end{array}$ & $\begin{array}{l}\text { Nickel, } \\
\text { water, } \\
\text { filtered, } \\
\text { in } \mu \mathrm{g} / \mathrm{L} \\
(01065)\end{array}$ \\
\hline $4 / 23 / 02$ & 1155 & 5.0 & $<10$ & $<8$ & $<10$ & $<13$ & $<6$ & 30 & $<0.08$ & 5.4 & $<0.01$ & $<50$ & $<30$ \\
\hline $9 / 11 / 02$ & 1130 & 5.9 & $<10$ & $<8$ & $<10$ & $<13$ & $<6$ & 80 & E.05 & 6.5 & $<.01$ & $<50$ & $<30$ \\
\hline Date & Time & $\begin{array}{c}\text { Selenium, } \\
\text { water, } \\
\text { filtered, } \\
\text { in } \mu \mathrm{g} / \mathrm{L} \\
(01145)\end{array}$ & $\begin{array}{c}\text { Silver, } \\
\text { water, } \\
\text { filtered, } \\
\text { in } \mu \mathrm{g} / \mathrm{L} \\
(01075)\end{array}$ & $\begin{array}{c}\text { Strontium, } \\
\text { water, } \\
\text { filtered, } \\
\text { in } \mu \mathrm{g} / \mathrm{L} \\
(01080)\end{array}$ & $\begin{array}{c}\text { Vanadium, } \\
\text { water, } \\
\text { filtered, } \\
\text { in } \mu \mathrm{g} / \mathrm{L} \\
(01085)\end{array}$ & $\begin{array}{l}\text { Zinc, } \\
\text { water, } \\
\text { filtered, } \\
\text { in } \mu \mathrm{g} / \mathrm{L} \\
(01090)\end{array}$ & $\begin{array}{l}\text { 1,4-Dichloro- } \\
\text { benzene, } \\
\text { water, } \\
\text { filtered, } \\
\text { in } \mu \mathrm{g} / \mathrm{L} \\
(34572)\end{array}$ & $\begin{array}{l}\text { 1-Methyl- } \\
\text { napthalene, } \\
\text { water, } \\
\text { filtered, } \\
\text { in } \mu \mathrm{g} / \mathrm{L} \\
(62054)\end{array}$ & $\begin{array}{c}2,6- \\
\text { Dimethyl- } \\
\text { napthalene, } \\
\text { water, } \\
\text { filtered, } \\
\text { in } \mu \mathrm{g} / \mathrm{L} \\
(62055)\end{array}$ & $\begin{array}{l}\text { 2-Methyl- } \\
\text { napthalene, } \\
\text { water, } \\
\text { filtered, } \\
\text { in } \mu \mathrm{g} / \mathrm{L} \\
(62056)\end{array}$ & $\begin{array}{c}\text { 3-beta-Copros- } \\
\text { tanol, } \\
\text { water, } \\
\text { filtered, } \\
\text { in } \mu \mathrm{g} / \mathrm{L} \\
(62057)\end{array}$ & $\begin{array}{l}\text { 3-Methyl-1H- } \\
\text { indole, } \\
\text { water, } \\
\text { filtered, } \\
\text { in } \mu \mathrm{g} / \mathrm{L} \\
(62058)\end{array}$ & $\begin{array}{l}\text { 3-tert-Butyl- } \\
\text { 4-hydroxy- } \\
\text { anisole, } \\
\text { water, } \\
\text { filtered, } \\
\text { in } \mu \mathrm{g} / \mathrm{L} \\
(62059)\end{array}$ \\
\hline $4 / 23 / 02$ & 1155 & $<2$ & $<9$ & 5.4 & $<8$ & $<24$ & $<0.5$ & $<0.5$ & $<0.5$ & $<0.5$ & $<2$ & $<1$ & $<5$ \\
\hline $9 / 11 / 02$ & 1130 & $<2$ & $<9$ & 5.9 & $<8$ & $<24$ & $<.5$ & $<.5$ & $<.5$ & $<.5$ & $<2$ & $<1$ & $<5$ \\
\hline
\end{tabular}


Table 2. Water-quality data from a small unnamed stream at Mt. Pisgah campground, Haywood County, North Carolina, April 23 and September 11, 2002.—Continued

$\left[\mathrm{ft}{ }^{3} / \mathrm{s}\right.$, cubic feet per second; $\mathrm{mg} / \mathrm{L}$, milligrams per liter; $\mu \mathrm{S} / \mathrm{cm}$, microsiemens per centimeter at 25 degrees Celsius; ${ }^{\circ} \mathrm{C}$, degrees Celsius; ANC, acid neutralizing capacity; $\mathrm{N}$, nitrogen; $\mathrm{P}$, phosphorus; col/100 $\mathrm{mL}$, colonies per 100 milliliters; $\mu \mathrm{g} / \mathrm{L}$, micrograms per liter; <, less than; E, estimated value; AHTN, acetyl hexamethyl tetrahydro naphthalene; M, presence verified, but not quantified; HHCB, hexahydrohexamethyl cyclopentabenzopyran]

\begin{tabular}{|c|c|c|c|c|c|c|c|c|c|c|c|c|c|}
\hline Date & Time & $\begin{array}{c}\text { 4-Cumyl- } \\
\text { phenol, } \\
\text { water, } \\
\text { filtered, } \\
\text { in } \mu \mathrm{g} / \mathrm{L} \\
(62060) \\
\end{array}$ & $\begin{array}{c}\text { 4-0ctyl- } \\
\text { phenol, } \\
\text { water, } \\
\text { filtered, } \\
\text { in } \mu \mathrm{g} / \mathrm{L} \\
(62061) \\
\end{array}$ & $\begin{array}{l}\text { 4-Nonyl- } \\
\text { phenol, } \\
\text { water, } \\
\text { filtered, } \\
\text { in } \mu \mathrm{g} / \mathrm{L} \\
(62085) \\
\end{array}$ & $\begin{array}{l}\text { 4-tert-0ctyl- } \\
\text { phenol, } \\
\text { water, } \\
\text { filtered, } \\
\text { in } \mu \mathrm{g} / \mathrm{L} \\
(62062) \\
\end{array}$ & $\begin{array}{c}\text { 5-Methyl-1H- } \\
\text { benzo- } \\
\text { triazole, } \\
\text { water, } \\
\text { filtered, } \\
\text { in } \mu \mathrm{g} / \mathrm{L} \\
(62063)\end{array}$ & $\begin{array}{c}\text { 9,10-Anthra- } \\
\text { quinone, } \\
\text { water, } \\
\text { filtered, } \\
\text { in } \mu \mathrm{g} / \mathrm{L} \\
(62066) \\
\end{array}$ & $\begin{array}{c}\text { Aceto- } \\
\text { phenone, } \\
\text { water } \\
\text { filtered, } \\
\text { in } \mu \mathrm{g} / \mathrm{L} \\
(62064)\end{array}$ & $\begin{array}{l}\text { AHTN, } \\
\text { water, } \\
\text { filtered, } \\
\text { in } \mu \mathrm{g} / \mathrm{L} \\
(62065) \\
\end{array}$ & $\begin{array}{c}\text { Anthracene, } \\
\text { water, } \\
\text { filtered, } \\
\text { in } \mu \mathrm{g} / \mathrm{L} \\
(34221) \\
\end{array}$ & $\begin{array}{c}\text { Benzo[a]- } \\
\text { pyrene, } \\
\text { water, } \\
\text { filtered, } \\
\text { in } \mu \mathrm{g} / \mathrm{L} \\
(34248) \\
\end{array}$ & $\begin{array}{c}\text { Benzophenone, } \\
\text { water, } \\
\text { filtered, } \\
\text { in } \mu \mathrm{g} / \mathrm{L} \\
(62067) \\
\end{array}$ & $\begin{array}{l}\text { beta-Sitos- } \\
\text { terol, water, } \\
\text { filtered, } \\
\text { in } \mu \mathrm{g} / \mathrm{L} \\
(62068)\end{array}$ \\
\hline $4 / 23 / 02$ & 1155 & $<1$ & $<1$ & $<5$ & $<1$ & $<2$ & $<0.5$ & $<0.5$ & $<0.5$ & $<0.5$ & $<0.5$ & $<0.5$ & $<2$ \\
\hline $9 / 11 / 02$ & 1130 & $<1$ & $<1$ & $<5$ & $<1$ & $<2$ & $<.5$ & $<.5$ & $<.5$ & $<.5$ & $<.5$ & $<.5$ & $<2$ \\
\hline Date & Time & $\begin{array}{c}\text { beta- } \\
\text { Stigma- } \\
\text { stanol, } \\
\text { water, } \\
\text { filtered, } \\
\text { in } \mu \mathrm{g} / \mathrm{L} \\
(620286)\end{array}$ & $\begin{array}{l}\text { Bisphenol } \\
\text { A, water, } \\
\text { filtered, } \\
\text { in } \mu \mathrm{g} / \mathrm{L} \\
(62069)\end{array}$ & $\begin{array}{l}\text { Bromacil, } \\
\text { water, } \\
\text { filtered, } \\
\text { in } \mu \mathrm{g} / \mathrm{L} \\
(04029)\end{array}$ & $\begin{array}{l}\text { Caffeine, } \\
\text { water, } \\
\text { filtered, } \\
\text { in } \mu \mathrm{g} / \mathrm{L} \\
(50305)\end{array}$ & $\begin{array}{l}\text { Camphor, } \\
\text { water, } \\
\text { filtered, } \\
\text { in } \mu \mathrm{g} / \mathrm{L} \\
(62070)\end{array}$ & $\begin{array}{c}\text { Carbaryl, } \\
\text { water, } \\
\text { filtered, } \\
0.7 \text { micron } \\
\text { glass fiber } \\
\text { filter, in } \mu \mathrm{g} / \mathrm{L} \\
(82680)\end{array}$ & $\begin{array}{l}\text { Carbazole, } \\
\text { water, } \\
\text { filtered, } \\
\text { in } \mu \mathrm{g} / \mathrm{L} \\
(62071)\end{array}$ & $\begin{array}{l}\text { Chlorpyrifos, } \\
\text { water, } \\
\text { filtered, } \\
\text { in } \mu \mathrm{g} / \mathrm{L} \\
(38933)\end{array}$ & $\begin{array}{l}\text { Cholesterol, } \\
\text { water, } \\
\text { filtered, } \\
\text { in } \mu \mathrm{g} / \mathrm{L} \\
(62072)\end{array}$ & $\begin{array}{l}\text { Cotinine, } \\
\text { water, } \\
\text { filtered, } \\
\text { in } \mu \mathrm{g} / \mathrm{L} \\
(62005)\end{array}$ & $\begin{array}{c}\text { DEET, } \\
\text { water, } \\
\text { filtered, } \\
\text { in } \mu \mathrm{g} / \mathrm{L} \\
(62082)\end{array}$ & $\begin{array}{l}\text { Diazinon, } \\
\text { water, } \\
\text { filtered, } \\
\text { in } \mu \mathrm{g} / \mathrm{L} \\
(39572)\end{array}$ \\
\hline $4 / 23 / 02$ & 1155 & $<2$ & $<1$ & $<0.5$ & $<0.5$ & $\mathrm{M}$ & $<1$ & $<0.5$ & $<0.5$ & $<2$ & $<1$ & $<0.5$ & $<0.5$ \\
\hline $9 / 11 / 02$ & 1130 & $<2$ & $<1$ & $<.5$ & $<.5$ & $<.5$ & $<1$ & $<.5$ & $<.5$ & $<2$ & $<1$ & E.1 & $<.5$ \\
\hline Date & Time & $\begin{array}{c}\text { Diethoxy- } \\
\text { nonylpheno } \\
\text { l, water, } \\
\text { filtered, } \\
\text { in } \mu \mathrm{g} / \mathrm{L} \\
(62083)\end{array}$ & $\begin{array}{l}\text { Diethoxy- } \\
\text { octylpheno } \\
\text { l, water, } \\
\text { filtered, } \\
\text { in } \mu \mathrm{g} / \mathrm{L} \\
(61705)\end{array}$ & $\begin{array}{c}\text { D- } \\
\text { Limonene, } \\
\text { water, } \\
\text { filtered, } \\
\text { in } \mu \mathrm{g} / \mathrm{L} \\
(62073)\end{array}$ & $\begin{array}{c}\text { Ethoxy- } \\
\text { octylphenol, } \\
\text { water, } \\
\text { filtered, } \\
\text { in } \mu \mathrm{g} / \mathrm{L} \\
(61706)\end{array}$ & $\begin{array}{l}\text { Fluoran- } \\
\text { thene, } \\
\text { water, } \\
\text { filtered, } \\
\text { in } \mu \mathrm{g} / \mathrm{L} \\
(34377)\end{array}$ & $\begin{array}{l}\text { HHCB, } \\
\text { water, } \\
\text { filtered, } \\
\text { in } \mu \mathrm{g} / \mathrm{L} \\
(62075)\end{array}$ & $\begin{array}{l}\text { Indole, } \\
\text { water } \\
\text { filtered, } \\
\text { in } \mu \mathrm{g} / \mathrm{L} \\
(62076)\end{array}$ & $\begin{array}{l}\text { Isoborneol, } \\
\text { water, } \\
\text { filtered, } \\
\text { in } \mu \mathrm{g} / \mathrm{L} \\
(62077)\end{array}$ & $\begin{array}{l}\text { Isophorone, } \\
\text { water, } \\
\text { filtered, } \\
\text { in } \mu \mathrm{g} / \mathrm{L} \\
(34409)\end{array}$ & $\begin{array}{c}\text { Isopropyl- } \\
\text { benzene, } \\
\text { water, } \\
\text { filtered, } \\
\text { in } \mu \mathrm{g} / \mathrm{L} \\
(62078)\end{array}$ & $\begin{array}{l}\text { Isoquinoline, } \\
\text { water, } \\
\text { filtered, } \\
\text { in } \mu \mathrm{g} / \mathrm{L} \\
(62079)\end{array}$ & $\begin{array}{l}\text { Menthol, } \\
\text { water, } \\
\text { filtered, } \\
\text { in } \mu \mathrm{g} / \mathrm{L} \\
(62080)\end{array}$ \\
\hline $4 / 23 / 02$ & 1155 & $<5$ & $<1$ & $<0.5$ & $<1$ & $<0.5$ & $<0.5$ & $<0.5$ & $<0.5$ & $<0.5$ & $<0.5$ & $<0.5$ & $<0.5$ \\
\hline $9 / 11 / 02$ & 1130 & $<5$ & $<1$ & $<.5$ & $<1$ & $<.5$ & $<.5$ & $<.5$ & $<.5$ & $<.5$ & $<.5$ & $<.5$ & $<.5$ \\
\hline Date & Time & $\begin{array}{l}\text { Metalaxyl, } \\
\text { water, } \\
\text { filtered, } \\
\text { in } \mu \mathrm{g} / \mathrm{L} \\
(50359)\end{array}$ & $\begin{array}{c}\text { Methyl } \\
\text { salicylate, } \\
\text { water, } \\
\text { filtered, } \\
\text { in } \mu \mathrm{g} / \mathrm{L} \\
(62081)\end{array}$ & $\begin{array}{c}\text { Metolachlo } \\
\text { r, water, } \\
\text { filtered, } \\
\text { in } \mu \mathrm{g} / \mathrm{L} \\
(39415)\end{array}$ & $\begin{array}{c}\text { Napthalene, } \\
\text { water, } \\
\text { filtered, } \\
\text { in } \mu \mathrm{g} / \mathrm{L} \\
(34443)\end{array}$ & $\begin{array}{l}\mathrm{p} \text {-Cresol, } \\
\text { water, } \\
\text { filtered, } \\
\text { in } \mu \mathrm{g} / \mathrm{L} \\
(62084)\end{array}$ & $\begin{array}{l}\text { Penta- } \\
\text { chlorophenol } \\
\text {, water, } \\
\text { filtered, } \\
\text { in } \mu \mathrm{g} / \mathrm{L} \\
(34459)\end{array}$ & $\begin{array}{l}\text { Phenan- } \\
\text { threne, } \\
\text { water, } \\
\text { filtered, } \\
\text { in } \mu \mathrm{g} / \mathrm{L} \\
(34462)\end{array}$ & $\begin{array}{l}\text { Phenol, } \\
\text { water, } \\
\text { filtered, } \\
\text { in } \mu \mathrm{g} / \mathrm{L} \\
(34466)\end{array}$ & $\begin{array}{l}\text { Prometon, } \\
\text { water, } \\
\text { filtered, } \\
\text { in } \mu \mathrm{g} / \mathrm{L} \\
(04037)\end{array}$ & $\begin{array}{l}\text { Pyrene, } \\
\text { water, } \\
\text { filtered, } \\
\text { in } \mu \mathrm{g} / \mathrm{L} \\
(34470)\end{array}$ & $\begin{array}{l}\text { Tetrachloro- } \\
\text { ethene, } \\
\text { water, } \\
\text { filtered, } \\
\text { in } \mu \mathrm{g} / \mathrm{L} \\
(34476)\end{array}$ & $\begin{array}{c}\text { Tribromo- } \\
\text { methane, } \\
\text { water, } \\
\text { filtered, } \\
\text { in } \mu \mathrm{g} / \mathrm{L} \\
(34288)\end{array}$ \\
\hline $4 / 23 / 02$ & 1155 & $<0.5$ & $<0.5$ & $<0.5$ & $<0.5$ & $<1$ & $<2$ & $<0.5$ & $<0.5$ & $<0.5$ & $<0.5$ & $<0.5$ & $<0.5$ \\
\hline $9 / 11 / 02$ & 1130 & $<.5$ & E. 1 & $<.5$ & $<.5$ & $<1$ & $<2$ & $<.5$ & $<.5$ & $<.5$ & $<.5$ & $<.5$ & $<.5$ \\
\hline Date & Time & $\begin{array}{c}\text { Tributyl- } \\
\text { phosphate, } \\
\text { water, } \\
\text { filtered, } \\
\text { in } \mu \mathrm{g} / \mathrm{L} \\
(62089)\end{array}$ & $\begin{array}{l}\text { Triclosan, } \\
\text { water, } \\
\text { filtered, } \\
\text { in } \mu \mathrm{g} / \mathrm{L} \\
(62090)\end{array}$ & $\begin{array}{l}\text { Triethyl- } \\
\text { citrate, } \\
\text { water, } \\
\text { filtered, } \\
\text { in } \mu \mathrm{g} / \mathrm{L} \\
(62091)\end{array}$ & $\begin{array}{c}\text { Triphenyl- } \\
\text { phosphate, } \\
\text { water, } \\
\text { filtered, } \\
\text { in } \mu \mathrm{g} / \mathrm{L} \\
(62092)\end{array}$ & $\begin{array}{c}\text { Tris }(2- \\
\text { butoxyethyl)p } \\
\text { hosphate, } \\
\text { water, } \\
\text { filtered, } \\
\text { in } \mu \mathrm{g} / \mathrm{L} \\
(62093)\end{array}$ & $\begin{array}{c}\text { Tris(2- } \\
\text { chloroethyl)- } \\
\text { phosphate, } \\
\text { water } \\
\text { filtered, } \\
\text { in } \mu \mathrm{g} / \mathrm{L} \\
(62087)\end{array}$ & $\begin{array}{c}\text { Tris- } \\
\text { (dichloro- } \\
\text { i-Pr) } \\
\text { phosphate, } \\
\text { water } \\
\text { filtered, } \\
\text { in } \mu \mathrm{g} / \mathrm{L} \\
(62088)\end{array}$ & $\begin{array}{l}\text { Dichlorvos, } \\
\text { water, } \\
\text { filtered, } \\
\text { in } \mu \mathrm{g} / \mathrm{L} \\
(38775)\end{array}$ & & & & \\
\hline $4 / 23 / 02$ & 1155 & $<0.5$ & $<1$ & $<0.5$ & $<0.5$ & $<0.5$ & $<0.5$ & $<0.5$ & $<1.00$ & & & & \\
\hline $9 / 11 / 02$ & 1130 & E. 3 & $<1$ & $<.5$ & $<.5$ & $<.5$ & $<.5$ & $<.5$ & $<1.00$ & & & & \\
\hline
\end{tabular}


Table 3. Selected water-quality data from samples collected in shallow wells and an unnamed tributary to Pisgah Creek at Mt. Pisgah campground, Haywood County, North Carolina, 2002.

[BLS, below land surface; ${ }^{\circ} \mathrm{C}$, degrees Celsius; field, measurement made in the field; $\mu \mathrm{S} / \mathrm{cm}$, microsiemens per centimeter at $25^{\circ} \mathrm{C}$; cols/100 mL, colonies per $100 \mathrm{milliliters;} \mathrm{NC}$ lab, analysis by the North Carolina Department of Environment and Natural Resources Laboratory, Asheville, N.C.; NWQL, analysis by the U.S. Geological Survey National Water Quality Laboratory, Denver, Colo.; mg/L, milligrams per liter; spec, analysis with a spectrophotometer, U.S. Geological Survey District laboratory, Raleigh, N.C.; ITS, indicator test strip; ---, not applicable or not analyzed; DO, dissolved oxygen; \%, percent;

ND, not detected; (e), estimated; <, less than]

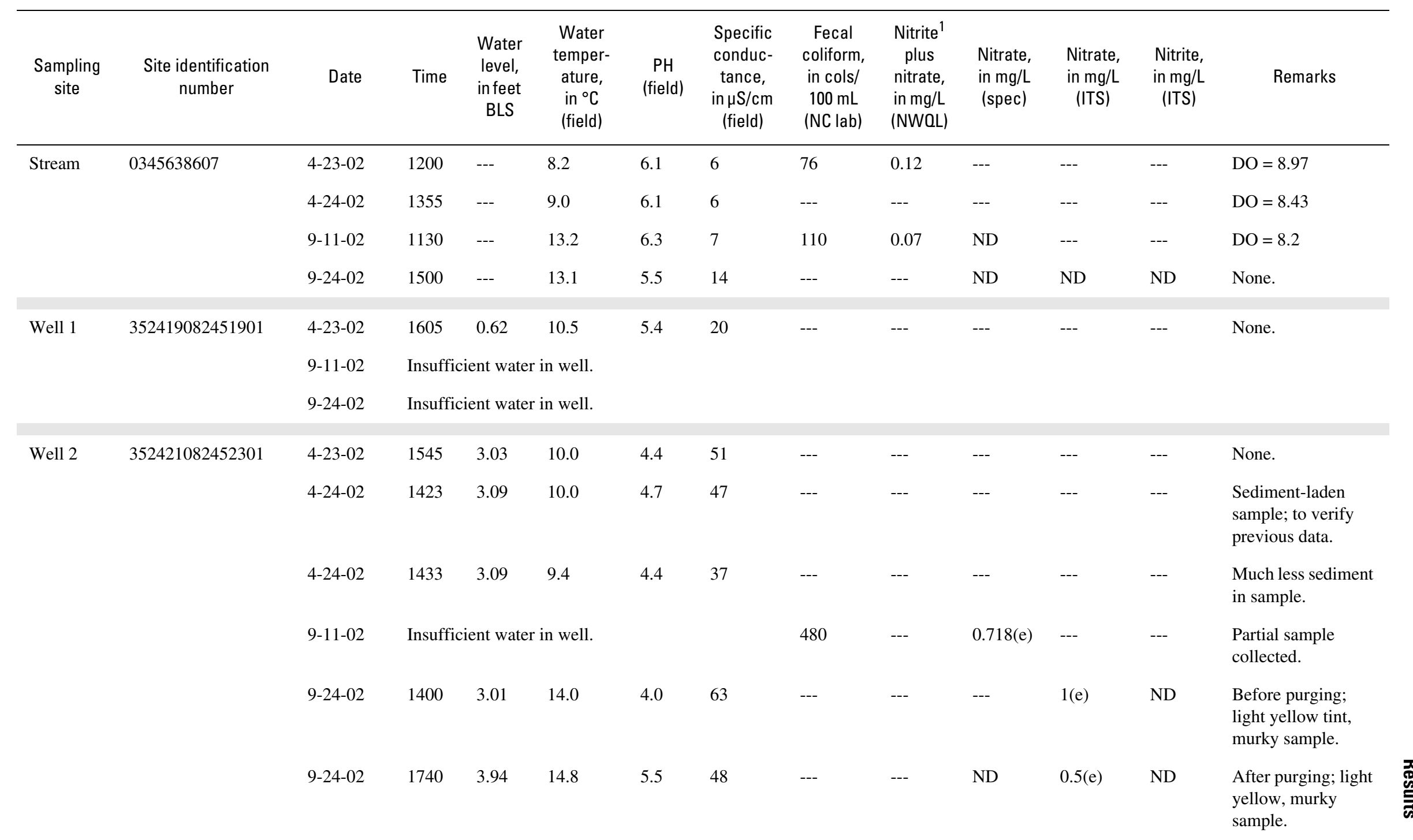


Table 3. Selected water-quality data from samples collected in shallow wells and an unnamed tributary to Pisgah Creek at Mt. Pisgah campground, Haywood County, North Carolina, 2002.-Continued

[BLS, below land surface; ${ }^{\circ} \mathrm{C}$, degrees Celsius; field, measurement made in the field; $\mu \mathrm{S} / \mathrm{cm}$, microsiemens per centimeter at $25^{\circ} \mathrm{C}$; cols $/ 100 \mathrm{~mL}$, colonies per $100 \mathrm{milliliters;} \mathrm{NC}$ lab, analysis by the North Carolina Department of Environment and Natural Resources Laboratory, Asheville, N.C.; NWQL, analysis by the U.S. Geological Survey National Water Quality Laboratory, Denver, Colo.; mg/L, milligrams per liter; spec, analysis with a spectrophotometer, U.S. Geological Survey District laboratory, Raleigh, N.C.; ITS, indicator test strip; ---, not applicable or not analyzed; DO, dissolved oxygen; \%, percent; ND, not detected; (e), estimated; <, less than]

\begin{tabular}{|c|c|c|c|c|c|c|c|c|c|c|c|c|c|}
\hline $\begin{array}{l}\text { Sampling } \\
\text { site }\end{array}$ & $\begin{array}{c}\text { Site identification } \\
\text { number }\end{array}$ & Date & Time & $\begin{array}{l}\text { Water } \\
\text { level, } \\
\text { infeet } \\
\text { BLS }\end{array}$ & $\begin{array}{c}\text { Water } \\
\text { temper- } \\
\text { ature, } \\
\text { in }{ }^{\circ} \mathrm{C} \\
\text { (field) }\end{array}$ & $\begin{array}{c}\mathrm{PH} \\
\text { (field) }\end{array}$ & $\begin{array}{c}\text { Specific } \\
\text { conduc- } \\
\text { tance, } \\
\text { in } \mu \mathrm{S} / \mathrm{cm} \\
\text { (field) }\end{array}$ & $\begin{array}{c}\text { Fecal } \\
\text { coliform, } \\
\text { in cols/ } \\
100 \mathrm{~mL} \\
\text { (NC lab) }\end{array}$ & $\begin{array}{l}\text { Nitrite }^{1} \\
\text { plus } \\
\text { nitrate, } \\
\text { in } \mathrm{mg} / \mathrm{L} \\
\text { (NWOL) }\end{array}$ & $\begin{array}{l}\text { Nitrate, } \\
\text { in mg/L } \\
\text { (spec) }\end{array}$ & $\begin{array}{l}\text { Nitrate, } \\
\text { in } \mathrm{mg} / \mathrm{L} \\
\text { (ITS) }\end{array}$ & $\begin{array}{c}\text { Nitrite, } \\
\text { in } \mathrm{mg} / \mathrm{L} \\
\text { (ITS) }\end{array}$ & Remarks \\
\hline \multirow[t]{4}{*}{ Well 3} & 352422082452001 & $4-23-02$ & 1644 & 0.21 & 12.4 & 6.0 & 19 & --- & --- & --- & --- & --- & None. \\
\hline & & $9-11-02$ & 1510 & --- & 14.6 & 6.2 & 68 & 8 & --- & ND & --- & --- & Murky sample. \\
\hline & & $9-24-02$ & 1315 & 0.31 & 15.1 & 6.2 & 52 & --- & --- & --- & ND & ND & $\begin{array}{l}\text { Before purging; } \\
\text { clear sample. }\end{array}$ \\
\hline & & $9-24-02$ & 1655 & 0.35 & 15.7 & 6.3 & 56 & --- & --- & $\mathrm{ND}$ & ND & ND & $\begin{array}{l}\text { After purging; clear } \\
\text { sample. }\end{array}$ \\
\hline \multirow[t]{4}{*}{ Well 4} & 352423082452001 & 4-23-02 & 1632 & 1.67 & 10.0 & 5.8 & 12 & --- & --- & --- & --- & --- & None. \\
\hline & & $9-11-02$ & 1500 & --- & 13.7 & 5.7 & 10 & 8 & --- & ND & --- & --- & Sample fairly clear. \\
\hline & & $9-24-02$ & 1252 & 1.70 & 13.9 & 5.7 & 15 & --- & --- & --- & ND & ND & $\begin{array}{l}\text { Before purging; } \\
\text { clear sample. }\end{array}$ \\
\hline & & $9-24-02$ & 1637 & 1.76 & 14.2 & 5.7 & 15 & --- & --- & ND & ND & ND & $\begin{array}{l}\text { After purging; clear } \\
\text { sample. }\end{array}$ \\
\hline \multirow[t]{5}{*}{ Well 5} & 352423082452501 & $4-23-02$ & 1529 & 0.14 & 11.5 & 5.7 & 28 & --- & --- & --- & --- & --- & None. \\
\hline & & 4-24-02 & 1407 & 0.10 & 10.4 & 5.6 & 30 & --- & --- & --- & --- & --- & $\begin{array}{l}\text { Readings to verify } \\
\text { accuracy of } \\
\text { previous day's data. }\end{array}$ \\
\hline & & $9-11-02$ & 1545 & --- & 14.7 & 5.6 & 36 & 16 & --- & ND & --- & --- & $\begin{array}{l}\text { Relatively clear } \\
\text { sample. }\end{array}$ \\
\hline & & $9-24-02$ & 1129 & 0.19 & 15.4 & 5.6 & 33 & --- & --- & --- & ND & ND & $\begin{array}{l}\text { Before purging; } \\
\text { sample a little } \\
\text { murky. }\end{array}$ \\
\hline & & $9-24-02$ & 1545 & 0.22 & 15.8 & 5.5 & 34 & --- & --- & ND & ND & ND & $\begin{array}{l}\text { After purging; } \\
\text { slightly yellow and } \\
\text { murky; H2S odor. }\end{array}$ \\
\hline
\end{tabular}


Table 3. Selected water-quality data from samples collected in shallow wells and an unnamed tributary to Pisgah Creek at Mt. Pisgah campground, Haywood County, North Carolina, 2002.-Continued

[BLS, below land surface; ${ }^{\circ} \mathrm{C}$, degrees Celsius; field, measurement made in the field; $\mu \mathrm{S} / \mathrm{cm}$, microsiemens per centimeter at $25^{\circ} \mathrm{C}$; cols $/ 100 \mathrm{~mL}$, colonies per $100 \mathrm{milliliters;} \mathrm{NC}$ lab, analysis by the North Carolina Department of Environment and Natural Resources Laboratory, Asheville, N.C.; NWQL, analysis by the U.S. Geological Survey National Water Quality Laboratory, Denver, Colo.; mg/L, milligrams per liter; spec, analysis with a spectrophotometer, U.S. Geological Survey District laboratory, Raleigh, N.C.; ITS, indicator test strip; ---, not applicable or not analyzed; DO, dissolved oxygen; \%, percent; ND, not detected; (e), estimated; <, less than]

\begin{tabular}{|c|c|c|c|c|c|c|c|c|c|c|c|c|c|}
\hline $\begin{array}{l}\text { Sampling } \\
\text { site }\end{array}$ & $\begin{array}{c}\text { Site identification } \\
\text { number }\end{array}$ & Date & Time & $\begin{array}{l}\text { Water } \\
\text { level, } \\
\text { infeet } \\
\text { BLS }\end{array}$ & $\begin{array}{l}\text { Water } \\
\text { temper- } \\
\text { ature, } \\
\text { in }{ }^{\circ} \mathrm{C} \\
\text { (field) }\end{array}$ & $\begin{array}{c}\mathrm{PH} \\
\text { (field) }\end{array}$ & $\begin{array}{c}\text { Specific } \\
\text { conduc- } \\
\text { tance, } \\
\text { in } \mu S / \mathrm{cm} \\
\text { (field) }\end{array}$ & $\begin{array}{c}\text { Fecal } \\
\text { coliform, } \\
\text { in cols/ } \\
100 \mathrm{~mL} \\
\text { (NC lab) }\end{array}$ & $\begin{array}{c}\text { Nitrite }^{1} \\
\text { plus } \\
\text { nitrate, } \\
\text { in mg/L } \\
\text { (NWQL) }\end{array}$ & $\begin{array}{c}\text { Nitrate, } \\
\text { in } \mathrm{mg} / \mathrm{L} \\
\text { (spec) }\end{array}$ & $\begin{array}{c}\text { Nitrate, } \\
\text { in } \mathrm{mg} / \mathrm{L} \\
\text { (ITS) }\end{array}$ & $\begin{array}{c}\text { Nitrite, } \\
\text { in } \mathrm{mg} / \mathrm{L} \\
\text { (ITS) }\end{array}$ & Remarks \\
\hline \multirow[t]{4}{*}{ Well 6} & 352426082452001 & $4-23-02$ & 1714 & 0.11 & 10.4 & 5.7 & 12 & --- & --- & --- & --- & --- & None. \\
\hline & & $9-11-02$ & 1445 & --- & 15.7 & 6.0 & 42 & 4 & --- & $0.876(e)$ & --- & --- & $\begin{array}{l}\text { Sample high in } \\
\text { sediment, heavily } \\
\text { laden. }\end{array}$ \\
\hline & & $9-24-02$ & 1220 & 0.29 & 14.9 & 5.7 & 19 & --- & --- & --- & ND & ND & $\begin{array}{l}\text { Before purging; } \\
\text { clear sample. }\end{array}$ \\
\hline & & $9-24-02$ & 1610 & 0.27 & 15.6 & 5.7 & 21 & --- & --- & ND & --- & --- & $\begin{array}{l}\text { After purging; clear } \\
\text { sample. }\end{array}$ \\
\hline \multirow[t]{4}{*}{ Well 7} & 352428082452601 & $4-23-02$ & 1457 & 5.18 & 9.7 & 4.7 & 13 & --- & --- & --- & --- & --- & None. \\
\hline & & $9-11-02$ & 1415 & --- & 17.4 & 5.0 & 14 & $<10$ & --- & $1.024(\mathrm{e})$ & --- & --- & None. \\
\hline & & $9-24-02$ & 1052 & 4.26 & 14.3 & 4.6 & 18 & --- & --- & --- & ND & ND & $\begin{array}{l}\text { Before purging; } \\
\text { clear sample. }\end{array}$ \\
\hline & & $9-24-02$ & 1520 & 4.40 & 15.2 & 4.7 & 19 & --- & --- & ND & ND & ND & $\begin{array}{l}\text { After purging; clear } \\
\text { sample. }\end{array}$ \\
\hline
\end{tabular}

${ }^{1}$ See table 2 . 


\section{Ground-Water Levels}

Ground-water levels were measured periodically in the seven shallow wells and two shallow piezometers located in the study area (fig. 2). Drought conditions occurred in many parts of the Blue Ridge Province for much of the study period. As a result, ground-water levels during periods of higher rainfall may differ from those defined in this report. Ground-water levels for 2002 generally were highest in the spring and lowest in the fall. Graphs of periodic ground-water-level measurements made in wells 1-7 and piezometers A and B are shown in figures 7-11. All water-level measurements made during the study are presented in the appendix (table A2).

\section{Ground-Water Quality}

Field measurements of water temperature, $\mathrm{pH}$, and specific conductance were made in samples collected from wells 1-7 in April and September 2002. Supplemental samples for fecal coliform densities were collected once on September 11, 2002, and samples for nitrate analysis only were collected twice from wells 2-7 on September 11 and 24, 2002 (table 3).

Values of $\mathrm{pH}$ measured in ground-water samples collected in April and September ranged from 4.0 to 6.3. Measured pH values were consistently lower in samples from wells 2 and 7 than in samples from the other wells. Additionally, measured pH values were consistently highest in samples from well 3 (table 3 ).

Specific-conductance values measured in samples collected from wells on the east side of the natural area were lower than those measured in samples from the other wells and generally were higher than conductance values measured in the stream (table 3). Mean specific-conductance values measured in samples from wells 4 and 6 were 13 and $24 \mu \mathrm{S} / \mathrm{cm}$, respectively. However, specific-conductance values measured in samples from two wells on the west side of the natural area were two to three times higher, averaging 49 and $32 \mu \mathrm{S} / \mathrm{cm}$ in wells 2 and 5, respectively. Specific-conductance values measured in samples collected from well 3, located near the center of the natural area, averaged $49 \mu \mathrm{S} / \mathrm{cm}$, also two to three times higher than those measured in samples from wells on the east side of the natural area (table 3).

As a result of differences observed in the specific conductance of ground-water samples collected in April, supplemental samples analyzed for fecal coliform bacteria and nitrate were collected from wells 2-7 on September 11, 2002. In addition, samples were collected from the same six wells and analyzed for nitrate concentrations only on September 24, 2002. Indicator test strips also were used in the field on September 24, 2002 to screen for nitrate and nitrite in ground-water samples collected from wells $2-7$.

From samples collected on September 11, fecal coliform densities in wells 3, 4, 6, and 7 generally were less than or equal to $8 \mathrm{col} / 100 \mathrm{~mL}$. The sample collected on the same date from well 5 had a coliform density twice as high (16 col/100 mL). More significantly, the sample collected from well 2 on September 11 had $480 \mathrm{col} / 100 \mathrm{~mL}, 60$ times as high as the coliform count for wells 3, 4, 6, and 7 (table 3).

Samples for nitrate concentrations were collected from wells 2-7 on September 11 and analyzed with a spectrophotometer at the USGS North Carolina District Office. Analytical results for these samples indicated that nitrate was present in wells 2, 6, and 7 at estimated concentrations of 1 milligram per liter $(\mathrm{mg} / \mathrm{L})$ or less (table 3 ). Nitrate was not detected in samples collected from any of the other wells on September 11.

Additional samples were collected from wells 2-7 on September 24 that were analyzed with a spectrophotometer at the USGS North Carolina District Office for nitrate concentrations only. Nitrate was not detected with the spectrophotometer in any of these samples. Indicator test strips also were used in the field on September 24 to screen for nitrate and nitrite in samples from wells 2-7. The test strips detected the presence of nitrate in the sample from only one well (well 2) at an estimated concentration of $1 \mathrm{mg} / \mathrm{L}$ or less. The presence of nitrate was not indicated by test strips in any other wells. Nitrite was not indicated by the test strips in any of the samples collected from wells 2-7 on September 24. 

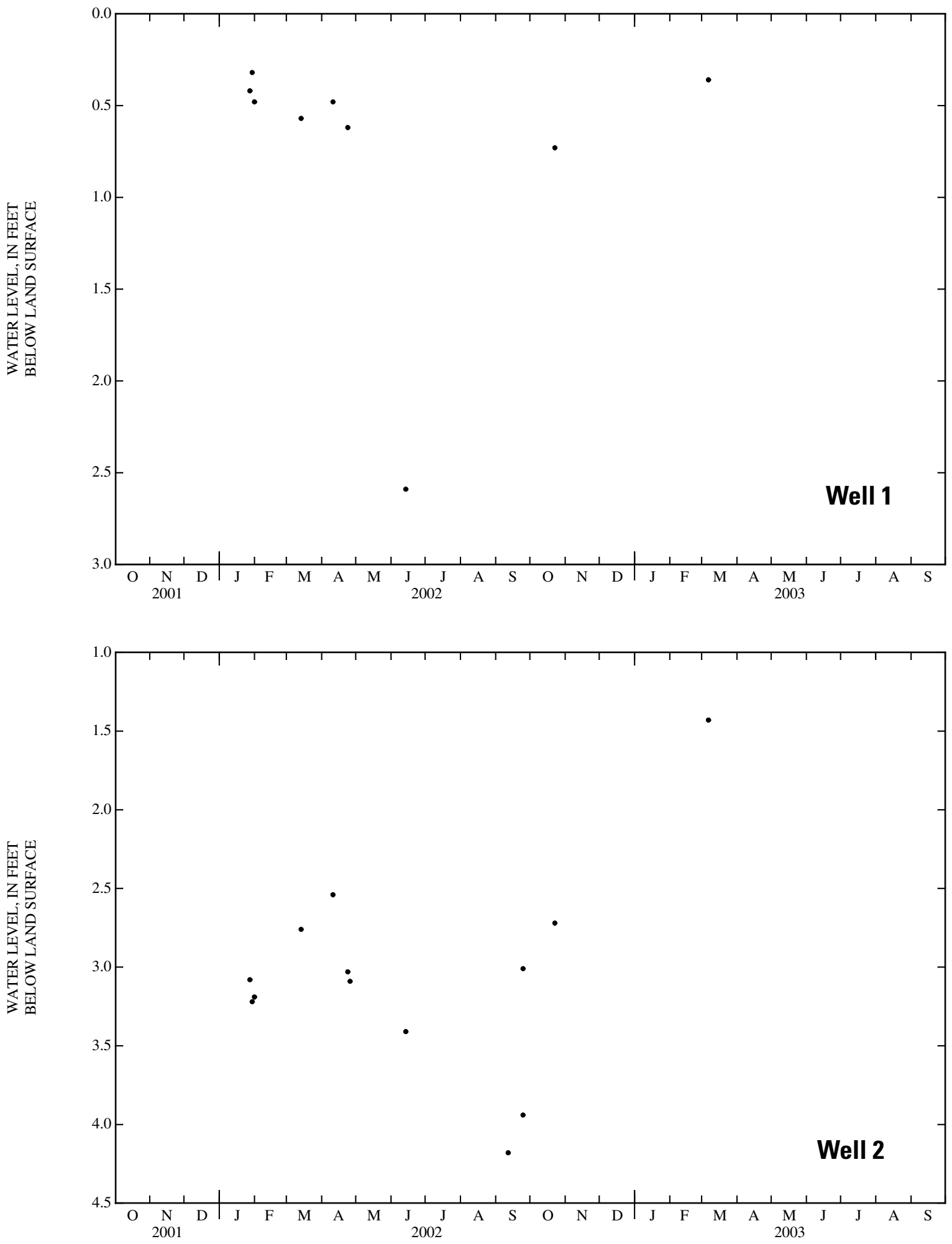

Figure 7. Periodic water levels measured in shallow wells 1 and 2 at the Mt. Pisgah campground, Haywood County, North Carolina. 

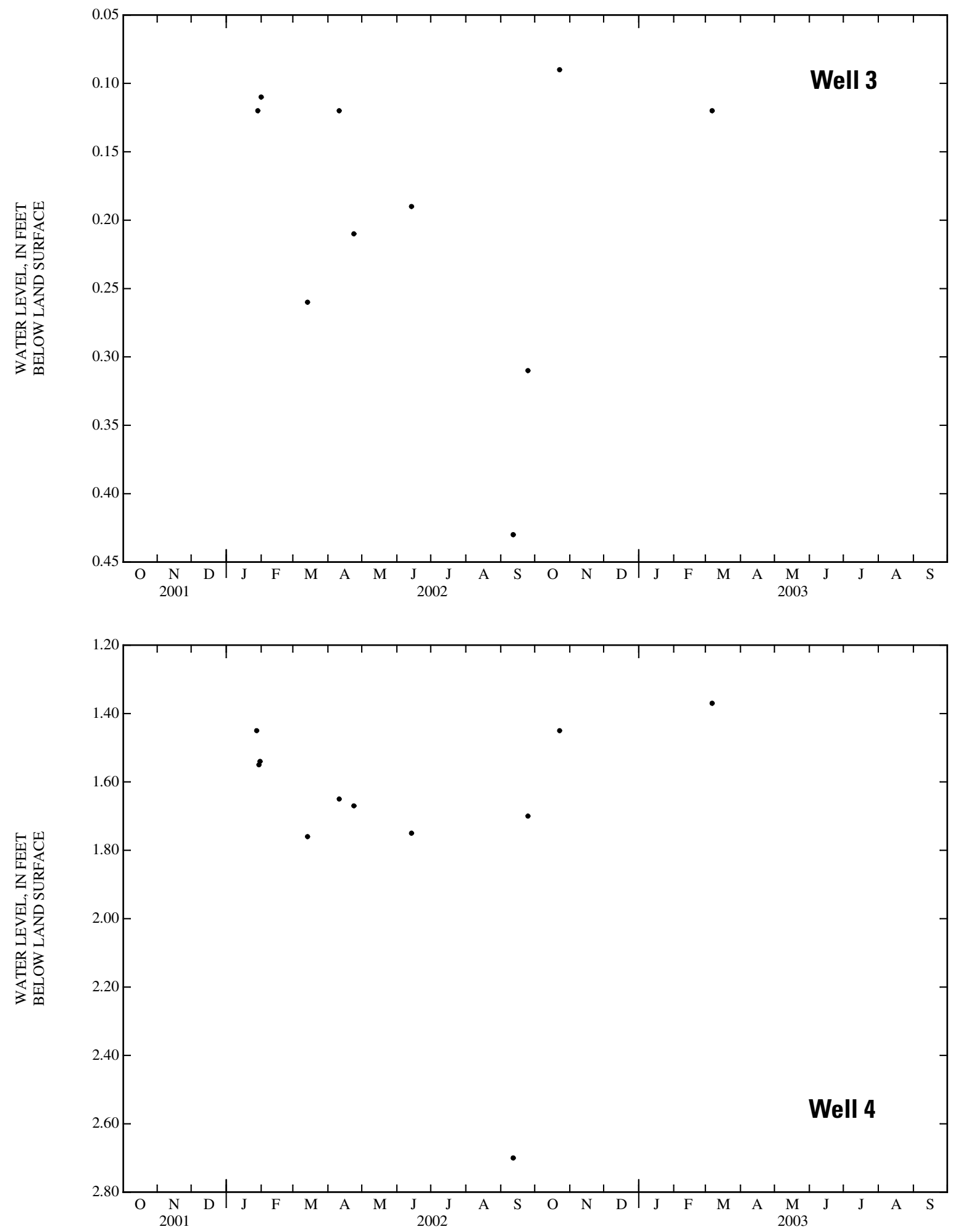

Figure 8. Periodic water levels measured in shallow wells 3 and 4 at the Mt. Pisgah campground, Haywood County, North Carolina. 

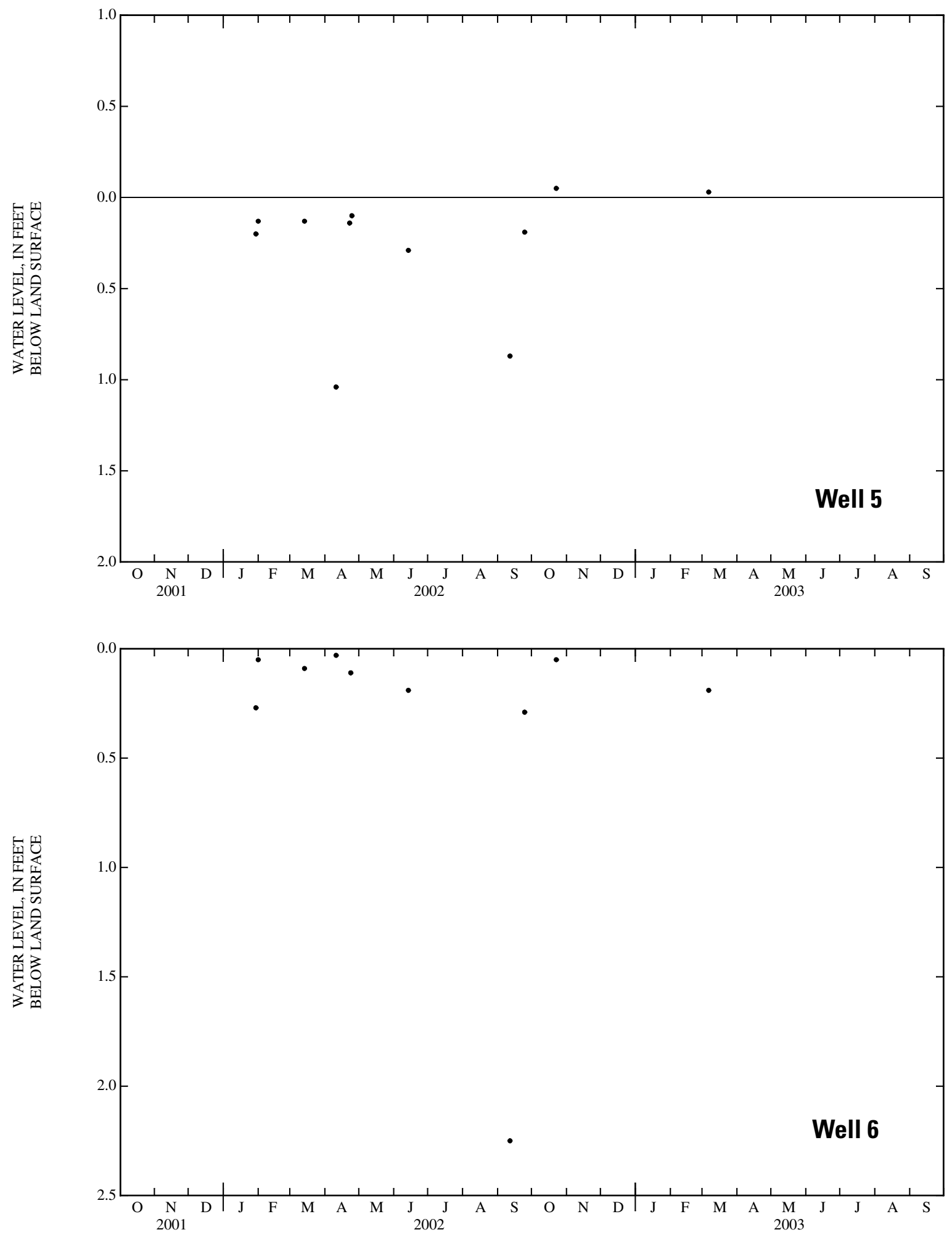

Figure 9. Periodic water levels measured in shallow wells 5 and 6 at the Mt. Pisgah campground, Haywood County, North Carolina. 


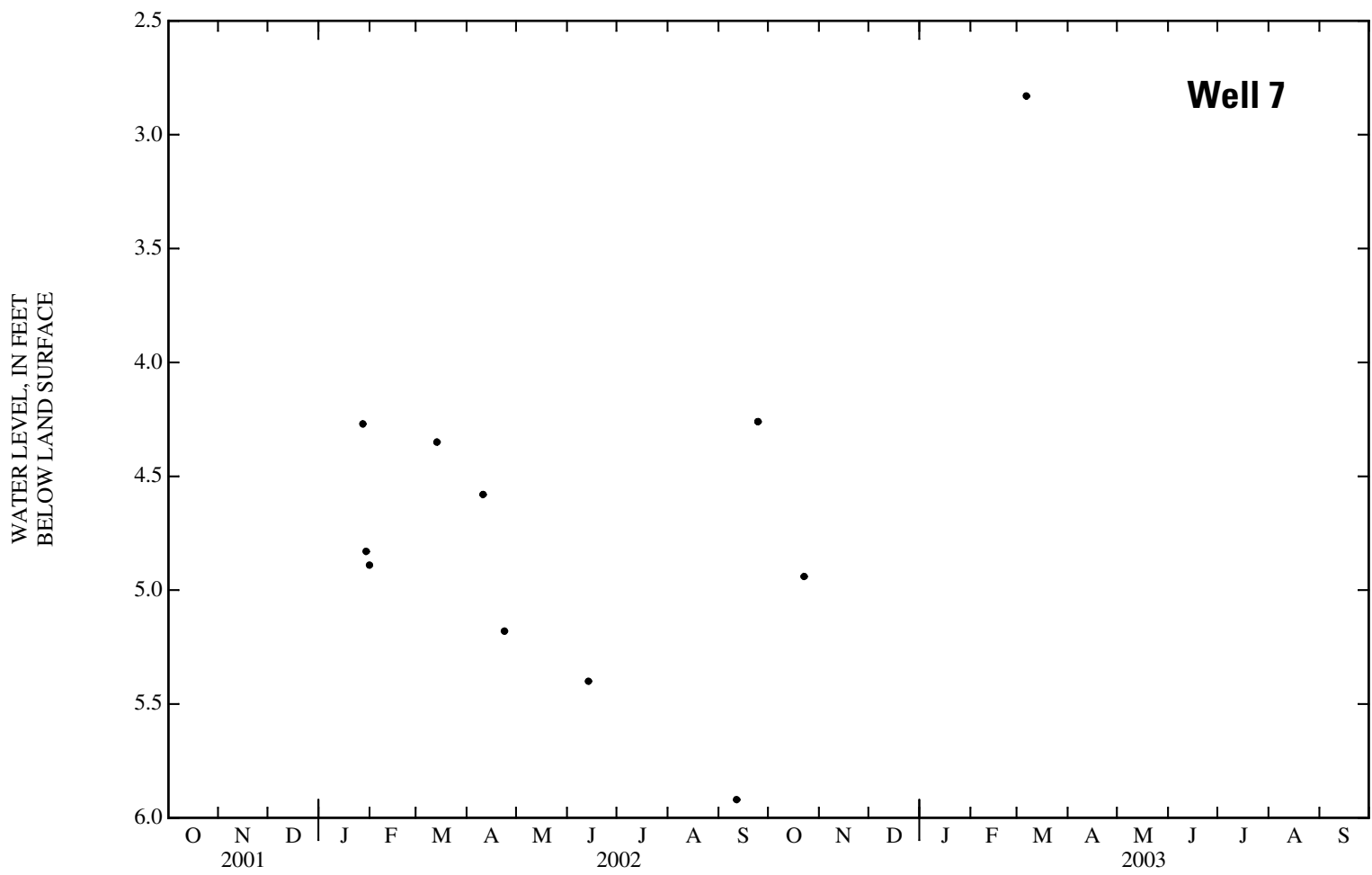

Figure 10. Periodic water levels measured in shallow well 7 at the Mt. Pisgah campground, Haywood County, North Carolina. 

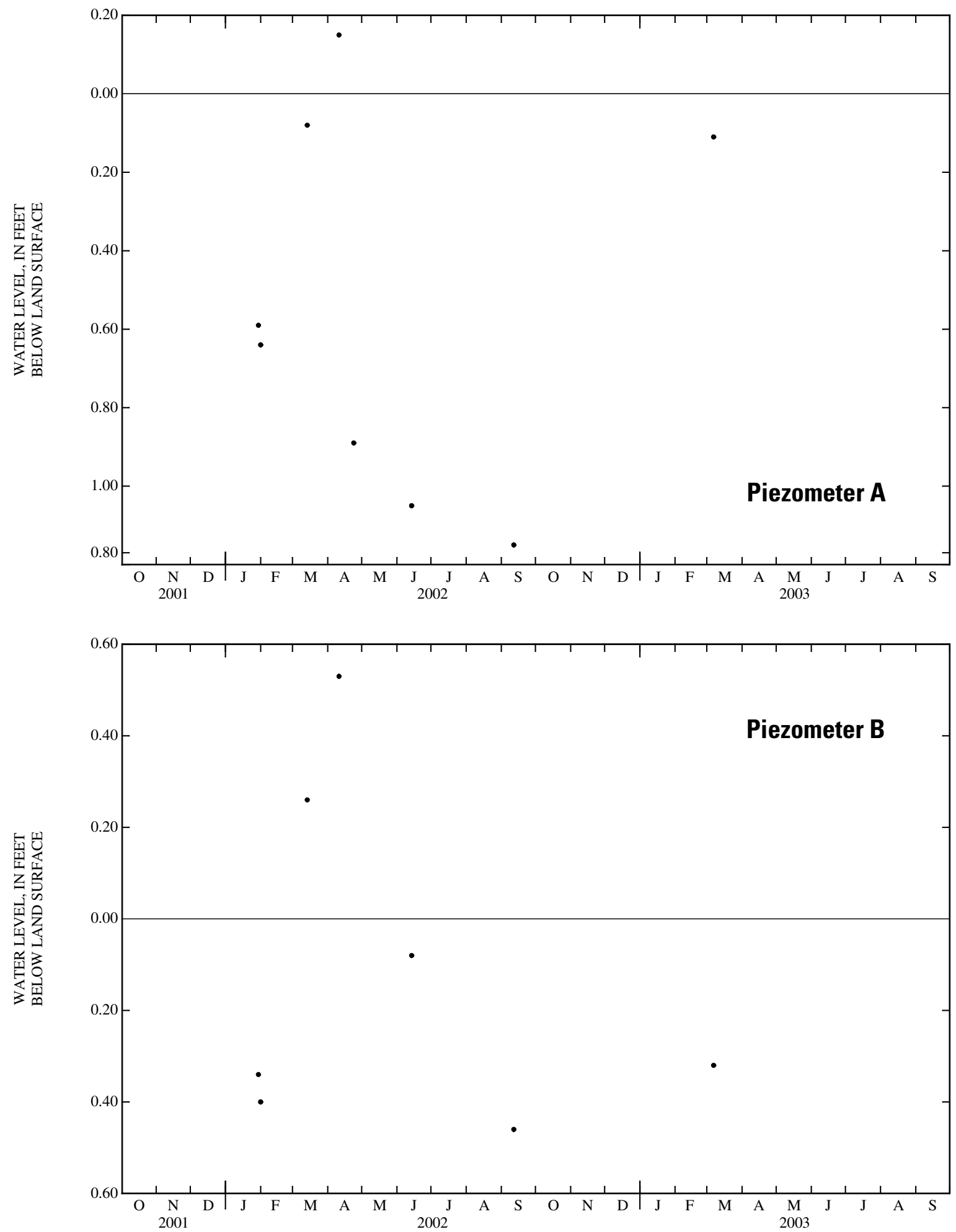

Figure 11. Periodic water levels measured in piezometers A and B at the Mt. Pisgah campground, Haywood County, North Carolina. 


\section{Suggestions for Further Study}

Further mapping of the heavily vegetated natural area in the center of the campground is needed to accurately define the extent of wetland and non-wetland areas. Many plant species growing in the center of the campground are evergreen, and growth is so dense that access to many parts of the natural area is, at best, extremely difficult. However, a complete and accurate delineation of all wetland boundaries would provide a valuable tool for monitoring and managing sensitive areas.

Although traces of some manmade compounds were detected in the stream draining the natural area, and some patterns were identified in specific conductance, fecal coliform, and nitrate concentrations detected in well samples, further study is needed to more accurately characterize stream- and ground-water-quality conditions at the Mt. Pisgah campground. Such an increased level of data collection and interpretation was beyond the scope of this study.

To better characterize water-quality conditions, additional water samples will need to be collected from the stream and the wells to identify consistent conditions and document seasonal trends. To facilitate comparisons, stream- and ground-water samples would need to be collected at least quarterly and analyzed for the same constituents, including major ions, nutrients, and wastewater compounds. Because well 1 went dry during the study, a new deeper well (installed to a depth of about $10 \mathrm{ft}$ below land surface) installed near well 1 would be necessary to enable ground-water-level measurements and sample collection during dry seasons. Additional ground-water samples collected from the area near well 1, the most upgradient well in the study area, may help to provide a more comprehensive set of ground-water-quality data. Future studies may also benefit from the installation of an additional well in the center of the natural area between wells 5 and 6 . This additional well would provide a means to compare conditions at different locations within the center of the natural area. With the addition of a second well installed in the interior part of the natural area, improved comparisons would be possible with wells that are located along the perimeter of the natural area.

\section{References}

Howe, S.S., Breton, P.L., and Chapman, M.J., 2003, Water resources data, North Carolina, Water year 2002, Volume 2-Groundwater records: U.S. Geological Survey Water-Data report NC-02-2, 355 p.

Ragland, B.C., Barker, R.G., and Robinson, J.B., 2004, Water Resources Data, North Carolina, Water Year 2003, Volume 1A-Surface-Water Records: U.S. Geological Survey Water-Data Report NC-03-1A, 701 p.

Ragland, B.C., Walters, D.A., Cartano, G.D., and Taylor, J.E., 2004, Water Resources Data, North Carolina, Water Year 2003, Volume 1B-Surface-Water Records: U.S. Geological Survey Water-Data Report NC-03-1B, 773 p.

Rantz, S.E., and others, 1982, Measurement and computation of streamflow-Volume 1. Measurement of stage and discharge: U.S. Geological Survey Water-Supply Paper 2175, 284 p.

Simmons, C.E., and Heath, R.C., 1982, Water-quality characteristics of streams in forested and rural areas of North Carolina: U.S. Geological Survey Water-Supply Paper 2185-B, 33 p.

Zaugg, S.D., Smith, S.G., Schroeder, M.P., Barber, L.B., and Burkhardt, M.R., 2002, Methods of analysis by the U.S. Geological Survey National Water Quality Laboratory-Determination of wastewater compounds by polystyrene-divinylbenzene solidphase extraction and capillary-column gas chromatography/mass spectrometry: U.S. Geological Survey Water-Resources Investigations Report 01-4186, 37 p. 
Appendixes 
Appendix Table A1. Maximum, minimum, and mean daily streamflow values for calendar year 2002 at Mt. Pisgah campground, Haywood County, North Carolina.

[Values are in cubic feet per second; ---, no data; e, estimated]

\begin{tabular}{|c|c|c|c|c|c|c|c|c|c|c|c|c|}
\hline \multirow{2}{*}{ Day } & \multicolumn{3}{|c|}{ January } & \multicolumn{3}{|c|}{ February } & \multicolumn{3}{|c|}{ March } & \multicolumn{3}{|c|}{ April } \\
\hline & Maximum & Minimum & Mean & Maximum & Minimum & Mean & Maximum & Minimum & Mean & Maximum & Minimum & Mean \\
\hline 1 & 0.47 & 0.40 & 0.42 & 0.37 & 0.34 & 0.34 & 0.34 & 0.31 & 0.31 & $\overline{---}$ & --- & $\mathrm{e} 0.44$ \\
\hline 2 & 0.44 & 0.37 & 0.38 & 0.34 & 0.34 & 0.34 & 1.9 & 0.31 & 0.63 & 0.44 & 0.40 & 0.40 \\
\hline 3 & 0.40 & 0.37 & 0.40 & 0.37 & 0.34 & 0.34 & 0.51 & 0.37 & 0.45 & 0.40 & 0.40 & 0.40 \\
\hline 4 & 0.40 & 0.37 & 0.38 & 0.34 & 0.31 & 0.33 & 0.37 & 0.34 & 0.36 & 0.40 & 0.37 & 0.40 \\
\hline 5 & 0.44 & 0.37 & 0.40 & 0.34 & 0.31 & 0.34 & 0.37 & 0.34 & 0.35 & 0.40 & 0.37 & 0.39 \\
\hline 6 & 0.51 & 0.40 & 0.42 & 0.55 & 0.34 & 0.38 & 0.37 & 0.34 & 0.34 & 0.40 & 0.37 & 0.39 \\
\hline 7 & 0.40 & 0.40 & 0.40 & 0.63 & 0.40 & 0.52 & 0.34 & 0.34 & 0.34 & 0.40 & 0.37 & 0.38 \\
\hline 8 & 0.40 & 0.37 & 0.40 & 0.40 & 0.37 & 0.37 & 0.34 & 0.34 & 0.34 & 0.40 & 0.37 & 0.40 \\
\hline 9 & 0.44 & 0.40 & 0.42 & 0.37 & 0.34 & 0.37 & 0.59 & 0.34 & 0.37 & 1.7 & 0.40 & 0.74 \\
\hline 10 & 0.51 & 0.40 & 0.45 & 0.47 & 0.37 & 0.43 & 0.37 & 0.31 & 0.34 & 0.82 & 0.44 & 0.50 \\
\hline 11 & 0.63 & 0.47 & 0.55 & 0.40 & 0.34 & 0.37 & 0.34 & 0.31 & 0.33 & 0.44 & 0.40 & 0.43 \\
\hline 12 & 0.47 & 0.44 & 0.47 & 0.37 & 0.34 & 0.34 & 0.72 & 0.31 & 0.47 & 0.44 & 0.40 & 0.42 \\
\hline 13 & 0.47 & 0.40 & 0.43 & 1.3 & 0.31 & 0.37 & 2.1 & 0.40 & 0.78 & 0.67 & 0.40 & 0.51 \\
\hline 14 & 0.40 & 0.37 & 0.40 & 0.34 & 0.31 & 0.32 & 0.44 & 0.37 & 0.38 & 0.63 & 0.44 & 0.46 \\
\hline 15 & 0.44 & 0.40 & 0.41 & 0.34 & 0.31 & 0.32 & 0.37 & 0.34 & 0.37 & 0.44 & 0.40 & 0.43 \\
\hline 16 & 0.44 & 0.40 & 0.43 & 0.34 & 0.31 & 0.31 & --- & --- & $\mathrm{e} 0.37$ & 0.44 & 0.34 & 0.40 \\
\hline 17 & 0.44 & 0.44 & 0.44 & 0.31 & 0.28 & 0.31 & 2.0 & 0.37 & 0.59 & 0.44 & 0.34 & 0.35 \\
\hline 18 & 0.44 & 0.40 & 0.44 & 0.31 & 0.28 & 0.31 & 0.72 & 0.44 & 0.47 & 0.34 & 0.34 & 0.34 \\
\hline 19 & 2.2 & 0.40 & 1.2 & 0.31 & 0.28 & 0.31 & 0.44 & 0.40 & 0.40 & 0.34 & 0.34 & 0.34 \\
\hline 20 & 0.98 & 0.55 & 0.65 & 0.55 & 0.28 & 0.35 & 0.47 & 0.40 & 0.44 & 0.34 & 0.34 & 0.34 \\
\hline 21 & 1.7 & 0.55 & 0.80 & 0.37 & 0.34 & 0.34 & 0.59 & 0.40 & 0.46 & 0.34 & 0.34 & 0.34 \\
\hline 22 & 0.59 & 0.51 & 0.54 & 0.34 & 0.31 & 0.34 & 0.44 & 0.37 & 0.39 & 0.34 & 0.31 & 0.33 \\
\hline 23 & 2.3 & 0.51 & 1.2 & 0.34 & 0.31 & 0.33 & 0.40 & 0.37 & 0.38 & 0.34 & 0.31 & 0.32 \\
\hline 24 & 2.0 & 0.72 & 0.95 & 0.34 & 0.31 & 0.32 & 0.40 & 0.37 & 0.37 & 0.31 & 0.31 & 0.31 \\
\hline 25 & 2.0 & 0.72 & 0.99 & 0.34 & 0.31 & 0.31 & 0.37 & 0.37 & 0.37 & 1.5 & 0.31 & 0.38 \\
\hline 26 & 0.72 & 0.63 & 0.67 & 0.34 & 0.31 & 0.31 & --- & --- & $\mathrm{e} 0.44$ & 0.31 & 0.31 & 0.31 \\
\hline 27 & 0.63 & 0.63 & 0.63 & 0.31 & 0.31 & 0.31 & 0.44 & 0.37 & 0.39 & 0.31 & 0.31 & 0.31 \\
\hline 28 & 0.63 & 0.59 & 0.61 & 0.34 & 0.31 & 0.31 & 0.37 & 0.37 & 0.37 & 0.31 & 0.31 & 0.31 \\
\hline 29 & 0.63 & 0.51 & 0.57 & --- & --- & --- & 0.37 & 0.37 & 0.37 & 0.31 & 0.28 & 0.31 \\
\hline 30 & 0.51 & 0.37 & 0.45 & --- & --- & --- & 1.2 & 0.37 & 0.54 & 0.31 & 0.28 & 0.30 \\
\hline 31 & 0.40 & 0.31 & 0.35 & --- & --- & --- & 1.1 & 0.44 & 0.53 & --- & --- & --- \\
\hline Month & 2.3 & 0.31 & 0.56 & 1.3 & 0.28 & 0.34 & --- & $\begin{array}{l}-- \\
\end{array}$ & 0.42 & $\begin{array}{l}-- \\
\end{array}$ & --- & 0.39 \\
\hline
\end{tabular}


Appendix Table A1. Maximum, minimum, and mean daily streamflow values for calendar year 2002 at Mt. Pisgah campground, Haywood County, North Carolina.- Continued [Values are in cubic feet per second; ---, no data; e, estimated]

\begin{tabular}{|c|c|c|c|c|c|c|c|c|c|c|c|c|}
\hline \multirow{2}{*}{ Day } & \multicolumn{3}{|c|}{ May } & \multicolumn{3}{|c|}{ June } & \multicolumn{3}{|c|}{ July } & \multicolumn{3}{|c|}{ August } \\
\hline & Maximum & Minimum & Mean & Maximum & Minimum & Mean & Maximum & Minimum & Mean & Maximum & Minimum & Mean \\
\hline 1 & 1.5 & 0.28 & 0.52 & 0.25 & 0.23 & 0.25 & 0.16 & 0.14 & 0.16 & 0.12 & 0.12 & 0.12 \\
\hline 2 & 0.34 & 0.31 & 0.32 & 0.25 & 0.23 & 0.24 & 1.2 & 0.14 & 0.18 & 0.12 & 0.12 & 0.12 \\
\hline 3 & 0.34 & 0.31 & 0.31 & 0.25 & 0.23 & 0.24 & 0.37 & 0.14 & 0.16 & 0.12 & 0.12 & 0.12 \\
\hline 4 & 2.5 & 0.31 & 0.74 & 0.25 & 0.23 & 0.23 & 0.18 & 0.14 & 0.15 & 0.12 & 0.10 & 0.11 \\
\hline 5 & 0.40 & 0.34 & 0.36 & 1.2 & 0.23 & 0.35 & 0.16 & 0.12 & 0.14 & 0.10 & 0.08 & 0.09 \\
\hline 6 & 0.34 & 0.31 & 0.34 & 0.44 & 0.23 & 0.26 & 0.14 & 0.10 & 0.12 & 0.10 & 0.08 & 0.09 \\
\hline 7 & 0.34 & 0.31 & 0.31 & 0.25 & 0.23 & 0.24 & 0.16 & 0.10 & 0.12 & 0.10 & 0.08 & 0.09 \\
\hline 8 & 0.34 & 0.31 & 0.32 & 0.23 & 0.23 & 0.23 & 0.14 & 0.10 & 0.11 & 0.10 & 0.08 & 0.08 \\
\hline 9 & 0.47 & 0.28 & 0.32 & 0.23 & 0.23 & 0.23 & 0.14 & 0.10 & 0.11 & 0.08 & 0.08 & 0.08 \\
\hline 10 & 0.31 & 0.31 & 0.31 & 0.23 & 0.20 & 0.22 & 0.23 & 0.10 & 0.12 & 0.08 & 0.08 & 0.08 \\
\hline 11 & 0.31 & 0.28 & 0.31 & 0.23 & 0.20 & 0.21 & 0.14 & 0.10 & 0.12 & 0.08 & 0.08 & 0.08 \\
\hline 12 & 0.31 & 0.28 & 0.31 & 0.23 & 0.20 & 0.20 & 0.16 & 0.10 & 0.12 & 0.08 & 0.06 & 0.08 \\
\hline 13 & 1.6 & 0.28 & 0.35 & 0.23 & 0.20 & 0.20 & 1.5 & 0.12 & 0.23 & 0.08 & 0.06 & 0.08 \\
\hline 14 & 0.34 & 0.28 & 0.30 & 0.23 & 0.20 & 0.20 & 0.18 & 0.14 & 0.15 & 0.08 & 0.06 & 0.08 \\
\hline 15 & 0.28 & 0.28 & 0.28 & 0.20 & 0.20 & 0.20 & 0.25 & 0.12 & 0.14 & 0.31 & 0.08 & 0.09 \\
\hline 16 & 0.28 & 0.28 & 0.28 & 0.20 & 0.20 & 0.20 & 0.31 & 0.20 & 0.25 & 0.67 & 0.08 & 0.11 \\
\hline 17 & 0.37 & 0.28 & 0.28 & 0.20 & 0.20 & 0.20 & 0.31 & 0.25 & 0.28 & 0.08 & 0.08 & 0.08 \\
\hline 18 & 1.3 & 0.28 & 0.38 & 0.20 & 0.20 & 0.20 & 0.28 & 0.25 & 0.26 & 7.0 & 0.06 & 0.35 \\
\hline 19 & 0.31 & 0.28 & 0.28 & 0.20 & 0.18 & 0.20 & 0.28 & 0.23 & 0.25 & 0.16 & 0.08 & 0.11 \\
\hline 20 & 0.28 & 0.28 & 0.28 & 0.20 & 0.16 & 0.19 & 0.25 & 0.10 & 0.18 & 0.08 & 0.06 & 0.07 \\
\hline 21 & 0.28 & 0.28 & 0.28 & 0.18 & 0.16 & 0.16 & 0.10 & 0.08 & 0.10 & 0.08 & 0.06 & 0.06 \\
\hline 22 & 0.28 & 0.28 & 0.28 & 0.18 & 0.16 & 0.16 & 0.10 & 0.08 & 0.10 & 0.06 & 0.06 & 0.06 \\
\hline 23 & 0.28 & 0.25 & 0.28 & 0.51 & 0.18 & 0.19 & 1.0 & 0.10 & 0.13 & 0.06 & 0.05 & 0.06 \\
\hline 24 & 0.28 & 0.25 & 0.26 & 0.18 & 0.16 & 0.17 & 8.4 & 0.10 & 0.48 & 0.06 & 0.06 & 0.06 \\
\hline 25 & 0.28 & 0.25 & 0.26 & 0.18 & 0.16 & 0.16 & 0.23 & 0.14 & 0.16 & 0.10 & 0.06 & 0.06 \\
\hline 26 & 0.63 & 0.25 & 0.29 & 0.51 & 0.16 & 0.19 & 0.14 & 0.12 & 0.13 & 0.08 & 0.06 & 0.06 \\
\hline 27 & 0.82 & 0.25 & 0.30 & 0.20 & 0.16 & 0.18 & 0.14 & 0.12 & 0.12 & 4.3 & 0.06 & 0.28 \\
\hline 28 & 0.28 & 0.25 & 0.26 & 0.18 & 0.16 & 0.16 & 0.14 & 0.12 & 0.13 & 0.08 & 0.06 & 0.08 \\
\hline 29 & 0.25 & 0.25 & 0.25 & 0.16 & 0.16 & 0.16 & 0.14 & 0.12 & 0.14 & 0.08 & 0.06 & 0.07 \\
\hline 30 & 0.25 & 0.25 & 0.25 & 0.16 & 0.16 & 0.16 & 0.16 & 0.12 & 0.13 & 0.08 & 0.06 & 0.07 \\
\hline 31 & 0.25 & 0.25 & 0.25 & --- & --- & --- & 0.14 & 0.12 & 0.12 & 0.10 & 0.06 & 0.08 \\
\hline Month & 2.5 & 0.25 & 0.32 & 1.2 & 0.16 & 0.21 & 8.4 & 0.08 & 0.16 & 7.0 & 0.05 & 0.10 \\
\hline
\end{tabular}


Appendix Table A1. Maximum, minimum, and mean daily streamflow values for calendar year 2002 at Mt. Pisgah campground, Haywood County, North Carolina.—Continued [Values are in cubic feet per second; ---, no data; e, estimated]

\begin{tabular}{|c|c|c|c|c|c|c|c|c|c|c|c|c|}
\hline \multirow{2}{*}{ Day } & \multicolumn{3}{|c|}{ September } & \multicolumn{3}{|c|}{ October } & \multicolumn{3}{|c|}{ November } & \multicolumn{3}{|c|}{ December } \\
\hline & Maximum & Minimum & Mean & Maximum & Minimum & Mean & Maximum & Minimum & Mean & Maximum & Minimum & Mean \\
\hline 1 & 0.10 & 0.08 & 0.08 & 0.67 & 0.40 & 0.66 & 0.40 & 0.37 & 0.40 & 0.47 & 0.44 & 0.45 \\
\hline 2 & 0.08 & 0.08 & 0.08 & 0.67 & 0.63 & 0.63 & 0.40 & 0.40 & 0.40 & 0.47 & 0.44 & 0.45 \\
\hline 3 & 0.10 & 0.06 & 0.08 & 0.63 & 0.59 & 0.63 & 0.40 & 0.37 & 0.40 & 0.47 & 0.44 & 0.44 \\
\hline 4 & 0.06 & 0.06 & 0.06 & 0.67 & 0.63 & 0.66 & 0.40 & 0.40 & 0.40 & 0.51 & 0.44 & 0.45 \\
\hline 5 & 0.06 & 0.06 & 0.06 & 0.67 & 0.63 & 0.63 & 2.3 & 0.40 & 0.71 & 1.0 & 0.51 & 0.70 \\
\hline 6 & 0.06 & 0.06 & 0.06 & 0.63 & 0.59 & 0.61 & 0.59 & 0.37 & 0.43 & 0.51 & 0.44 & 0.46 \\
\hline 7 & 0.06 & 0.05 & 0.06 & 0.59 & 0.59 & 0.59 & 0.40 & 0.37 & 0.38 & 0.44 & 0.40 & 0.43 \\
\hline 8 & 0.06 & 0.06 & 0.06 & 0.59 & 0.51 & 0.57 & 0.37 & 0.37 & 0.37 & 0.44 & 0.40 & 0.41 \\
\hline 9 & 0.06 & 0.05 & 0.06 & 0.55 & 0.51 & 0.53 & 0.55 & 0.37 & 0.38 & 0.40 & 0.40 & 0.40 \\
\hline 10 & 0.06 & 0.05 & 0.06 & 0.98 & 0.51 & 0.59 & 0.82 & 0.44 & 0.50 & 2.1 & 0.40 & 0.60 \\
\hline 11 & 0.06 & 0.05 & 0.06 & 0.63 & 0.55 & 0.58 & 4.3 & 0.51 & 1.1 & 2.5 & 0.59 & 0.87 \\
\hline 12 & 0.06 & 0.06 & 0.06 & 0.55 & 0.55 & 0.55 & 1.5 & 0.51 & 0.80 & 0.59 & 0.51 & 0.52 \\
\hline 13 & 0.12 & 0.06 & 0.07 & 0.55 & 0.51 & 0.55 & 0.55 & 0.47 & 0.51 & 2.0 & 0.51 & 1.0 \\
\hline 14 & 1.7 & 0.06 & 0.22 & 0.55 & 0.51 & 0.54 & 0.51 & 0.44 & 0.47 & 0.72 & 0.55 & 0.60 \\
\hline 15 & 1.0 & 0.16 & 0.41 & 2.2 & 0.51 & 1.1 & 1.8 & 0.44 & 0.58 & 0.55 & 0.51 & 0.52 \\
\hline 16 & 0.16 & 0.10 & 0.13 & 2.5 & 0.82 & 1.2 & 1.8 & 0.72 & 1.0 & 0.51 & 0.51 & 0.51 \\
\hline 17 & 0.10 & 0.10 & 0.10 & 0.82 & 0.67 & 0.73 & 0.98 & 0.55 & 0.70 & 0.51 & 0.47 & 0.50 \\
\hline 18 & 0.10 & 0.08 & 0.09 & 0.67 & 0.63 & 0.67 & 0.59 & 0.55 & 0.55 & 0.51 & 0.47 & 0.48 \\
\hline 19 & 0.08 & 0.06 & 0.08 & 0.67 & 0.55 & 0.61 & 0.55 & 0.51 & 0.54 & 5.4 & 0.47 & 0.95 \\
\hline 20 & 2.3 & 0.06 & 0.31 & 0.55 & 0.47 & 0.52 & 0.55 & 0.51 & 0.52 & 4.2 & 0.63 & 1.1 \\
\hline 21 & 1.5 & 0.20 & 0.43 & 0.47 & 0.40 & 0.45 & 0.67 & 0.55 & 0.59 & 0.63 & 0.55 & 0.59 \\
\hline 22 & 4.7 & 0.16 & 0.73 & 0.40 & 0.34 & 0.38 & 0.55 & 0.51 & 0.54 & 0.59 & 0.55 & 0.55 \\
\hline 23 & 0.34 & 0.14 & 0.20 & 0.37 & 0.34 & 0.36 & 0.51 & 0.51 & 0.51 & 0.55 & 0.51 & 0.55 \\
\hline 24 & 0.14 & 0.11 & 0.13 & 0.37 & 0.34 & 0.36 & 0.51 & 0.47 & 0.49 & 5.0 & 0.55 & 1.6 \\
\hline 25 & 1.6 & 0.11 & 0.23 & 0.63 & 0.34 & 0.42 & 0.51 & 0.47 & 0.50 & 1.2 & 0.77 & 0.88 \\
\hline 26 & 9.7 & 0.67 & 1.7 & 0.40 & 0.37 & 0.39 & 0.51 & 0.47 & 0.50 & 0.77 & 0.72 & 0.74 \\
\hline 27 & 9.7 & 0.82 & 3.1 & 0.37 & 0.37 & 0.37 & 0.51 & 0.47 & 0.48 & 0.72 & 0.72 & 0.72 \\
\hline 28 & 0.82 & 0.47 & 0.59 & 0.55 & 0.37 & 0.41 & 0.47 & 0.47 & 0.47 & 0.72 & 0.67 & 0.71 \\
\hline 29 & 0.51 & 0.44 & 0.47 & 0.51 & 0.40 & 0.44 & 0.47 & 0.44 & 0.47 & 0.72 & 0.67 & 0.72 \\
\hline 30 & 0.44 & 0.40 & 0.42 & 0.47 & 0.40 & 0.45 & 0.47 & 0.44 & 0.47 & 0.72 & 0.67 & 0.70 \\
\hline 31 & --- & --- & --- & 0.44 & 0.40 & 0.40 & --- & --- & --- & 3.3 & 0.67 & 0.89 \\
\hline Month & 9.7 & 0.05 & 0.34 & 2.5 & 0.34 & 0.57 & 4.3 & 0.37 & 0.54 & 5.4 & 0.40 & 0.66 \\
\hline
\end{tabular}


Appendix Table A2. Water-level data from shallow wells and piezometers at the Mt. Pisgah campground, Haywood County, North Carolina.

[Values are in feet; USGS, U.S. Geological Survey; ft, feet; msl, mean sea level; >, greater than]

\section{Well 1; USGS site no. 352419082451901; County no. HW-66}

Depth $=3.33 \mathrm{ft}$ below land surface

Land surface elevation $=4,873.4 \mathrm{ft}$ (above $\mathrm{msl}$ ); $36.4 \mathrm{ft}$ (gage datum)

Measuring point elevation = 4,877.04 ft (above $\mathrm{msl}$ ); $40.07 \mathrm{ft}$ (gage datum)

Measuring point to land surface $=3.65 \mathrm{ft}$

\begin{tabular}{clllll}
\hline Date & Time & $\begin{array}{c}\text { Water level } \\
\text { below land } \\
\text { surface }\end{array}$ & $\begin{array}{c}\text { Water level } \\
\text { below } \\
\text { measuring } \\
\text { point }\end{array}$ & $\begin{array}{c}\text { Water surface } \\
\text { (in gage } \\
\text { datum) }\end{array}$ & $\begin{array}{c}\text { Water } \\
\text { surface } \\
\text { elevation } \\
\text { (msl) }\end{array}$ \\
\hline $01 / 28 / 02$ & 1554 & 0.42 & 4.07 & 36.00 & $4,872.97$ \\
$01 / 30 / 02$ & 1325 & 0.32 & 3.97 & 36.10 & $4,873.07$ \\
$01 / 31 / 02$ & 1307 & 0.48 & 4.13 & 35.94 & $4,872.91$ \\
03.13 .02 & 1322 & 0.57 & 4.22 & 35.85 & $4,872.82$ \\
$04 / 10 / 02$ & 1220 & 0.48 & 4.13 & 35.94 & $4,872.91$ \\
$04 / 23 / 02$ & 1605 & 0.62 & 4.27 & 35.80 & $4,872.77$ \\
$06 / 13 / 02$ & 0953 & 2.59 & 6.24 & 33.83 & $4,870.80$ \\
$09 / 11 / 02$ & 1252 & Dry & Dry & Dry & Dry \\
$09 / 24 / 02$ & 1201 & Dry; $>2.99$ & $>6.64$ & Dry & Dry \\
$10 / 22 / 02$ & & 0.73 & 4.38 & 35.69 & $4,872.66$ \\
$03 / 06 / 03$ & 1027 & 0.36 & 4.01 & 36.06 & $4,873.03$ \\
\hline
\end{tabular}

Well 2; USGS site no. 352421082452301; County no. HW-67

Depth $=5.08 \mathrm{ft}$ below land surface

Land surface elevation = 4,857.0 ft (above msl); $20.0 \mathrm{ft}$ (gage datum)

Measuring point elevation = 4,858.95 ft (above $\mathrm{msl}$ ); $21.98 \mathrm{ft}$ (gage datum)

Measuring point to land surface $=2.00 \mathrm{ft}$

\begin{tabular}{|c|c|c|c|c|c|c|}
\hline Date & Time & $\begin{array}{c}\text { Water level } \\
\text { below land } \\
\text { surface }\end{array}$ & $\begin{array}{c}\text { Water level } \\
\text { below } \\
\text { measuring } \\
\text { point }\end{array}$ & $\begin{array}{l}\text { Water surface } \\
\text { (in gage } \\
\text { datum) }\end{array}$ & $\begin{array}{l}\text { Water } \\
\text { surface } \\
\text { elevation } \\
\text { (msl) }\end{array}$ & Remarks \\
\hline $01 / 29 / 02$ & 0930 & 3.08 & 5.08 & 16.90 & $4,853.87$ & \\
\hline $01 / 30 / 02$ & 1318 & 3.22 & 5.22 & 16.76 & $4,853.73$ & \\
\hline $01 / 31 / 02$ & 1220 & 3.19 & 5.19 & 16.79 & $4,853.76$ & \\
\hline 03/13/02 & 1318 & 2.76 & 4.76 & 17.22 & $4,854.19$ & \\
\hline $04 / 10 / 02$ & 1217 & 2.54 & 4.54 & 17.44 & $4,854.41$ & \\
\hline $04 / 23 / 02$ & 1545 & 3.03 & 5.03 & 16.95 & $4,853.92$ & \\
\hline $04 / 24 / 02$ & 1423 & 3.09 & 5.09 & 16.89 & $4,853.86$ & \\
\hline $06 / 13 / 02$ & 0955 & 3.41 & 5.41 & 16.57 & $4,853.54$ & \\
\hline $09 / 11 / 02$ & 1252 & 4.18 & 6.18 & 15.80 & $4,852.77$ & \\
\hline $09 / 24 / 02$ & 1355 & 3.01 & 5.01 & 16.97 & $4,853.94$ & Before purging. \\
\hline $10 / 22 / 02$ & & 2.72 & 4.72 & 17.26 & $4,854.23$ & \\
\hline 03/06/03 & 1027 & 1.43 & 3.43 & 18.55 & $4,855.52$ & \\
\hline
\end{tabular}


Appendix Table A2. Water-level data from shallow wells and piezometers at the Mt. Pisgah campground, Haywood County, North Carolina.-Continued

[Values are in feet; USGS, U.S. Geological Survey; ft, feet; msl, mean sea level; >, greater than]

\begin{tabular}{|c|c|c|c|c|c|c|}
\hline \multicolumn{7}{|c|}{ Well 3; USGS site no. 352422082452001; County no. HW-68 } \\
\hline \multicolumn{7}{|c|}{$\begin{array}{l}\text { Depth }=2.66 \mathrm{ft} \text { below land surface } \\
\text { Land surface elevation }=4,854.2 \mathrm{ft} \text { (above } \mathrm{msl} \text { ); } 17.2 \mathrm{ft} \text { (gage datum) } \\
\text { Measuring point elevation }=4,856.25 \mathrm{ft} \text { (above } \mathrm{msl} \text { ); } 19.28 \mathrm{ft} \text { (gage datum) } \\
\text { Measuring point to land surface }=2.05 \mathrm{ft}\end{array}$} \\
\hline Date & Time & $\begin{array}{l}\text { Water level } \\
\text { below land } \\
\text { surface }\end{array}$ & $\begin{array}{l}\text { Water level } \\
\text { below } \\
\text { measuring } \\
\text { point }\end{array}$ & $\begin{array}{l}\text { Water surface } \\
\text { (in gage } \\
\text { datum) }\end{array}$ & $\begin{array}{l}\text { Water } \\
\text { surface } \\
\text { elevation } \\
\text { (msl) }\end{array}$ & Remarks \\
\hline $01 / 29 / 02$ & 1500 & 1.74 & 3.79 & 15.49 & $4,852.46$ & \\
\hline $01 / 30 / 02$ & & 0.12 & 2.17 & 17.11 & $4,854.08$ & \\
\hline $01 / 31 / 02$ & 1340 & 0.11 & 2.16 & 17.12 & $4,854.09$ & \\
\hline $03 / 13 / 02$ & 1330 & 0.26 & 2.31 & 16.97 & $4,853.94$ & \\
\hline $04 / 10 / 02$ & 1225 & 0.12 & 2.17 & 17.11 & $4,854.08$ & \\
\hline $04 / 23 / 02$ & 1644 & 0.21 & 2.26 & 17.02 & $4,853.99$ & \\
\hline $06 / 13 / 02$ & 0948 & 0.19 & 2.24 & 17.04 & $4,854.01$ & \\
\hline $09 / 11 / 02$ & 1230 & 0.43 & 2.48 & 16.80 & $4,853.77$ & \\
\hline $09 / 24 / 02$ & 1310 & 0.31 & 2.36 & 16.92 & $4,853.89$ & Before purging. \\
\hline $10 / 22 / 02$ & & 0.09 & 2.14 & 17.14 & $4,854.11$ & \\
\hline 03/06/03 & 1023 & 0.12 & 2.17 & 17.11 & $4,854.08$ & \\
\hline
\end{tabular}

Depth $=3.90 \mathrm{ft}$ below land surface

Land surface elevation = 4,856.2 ft (above $\mathrm{msl}$ ); $19.2 \mathrm{ft}$ (gage datum)

Measuring point elevation = 4,859.31 ft (above $\mathrm{msl}$ ); $22.34 \mathrm{ft}$ (gage datum)

Measuring point to land surface $=3.10 \mathrm{ft}$

\begin{tabular}{clllll}
\hline Date & Time & $\begin{array}{c}\text { Water level } \\
\text { below land } \\
\text { surface }\end{array}$ & $\begin{array}{c}\text { Water level } \\
\text { below } \\
\text { measuring } \\
\text { point }\end{array}$ & $\begin{array}{c}\text { Water surface } \\
\text { (in gage } \\
\text { datum) }\end{array}$ & $\begin{array}{c}\text { Water } \\
\text { surface } \\
\text { elevation } \\
\text { (msI) }\end{array}$ \\
\hline $01 / 29 / 02$ & 1045 & 1.45 & 4.55 & 17.79 & $4,854.76$ \\
Remarks
\end{tabular}


Appendix Table A2. Water-level data from shallow wells and piezometers at the Mt. Pisgah campground, Haywood County, North Carolina.-Continued

[Values are in feet; USGS, U.S. Geological Survey; ft, feet; msl, mean sea level; >, greater than]

Well 5; USGS site no. 352423082452501; County no. HW-70

Depth $=2.78 \mathrm{ft}$ below land surface

Land surface elevation $=4,851.9 \mathrm{ft}$ (above $\mathrm{msl}$ ); $14.9 \mathrm{ft}$ (gage datum)

Measuring point elevation $=4,854.29 \mathrm{ft}$ (above $\mathrm{msl}$ ); $17.32 \mathrm{ft}$ (gage datum)

Measuring point to land surface $=2.40 \mathrm{ft}$

\begin{tabular}{|c|c|c|c|c|c|c|}
\hline Date & Time & $\begin{array}{c}\text { Water level } \\
\text { below land } \\
\text { surface }\end{array}$ & $\begin{array}{c}\text { Water level } \\
\text { below } \\
\text { measuring } \\
\text { point }\end{array}$ & $\begin{array}{c}\text { Water surface } \\
\text { (in gage } \\
\text { datum) }\end{array}$ & $\begin{array}{c}\text { Water } \\
\text { surface } \\
\text { elevation } \\
\text { (msl) }\end{array}$ & Remarks \\
\hline $01 / 30 / 02$ & & 0.20 & 2.60 & 14.72 & $4,851.69$ & \\
\hline $01 / 31 / 02$ & & 0.13 & 2.53 & 14.79 & $4,851.76$ & \\
\hline 03/13/02 & 1313 & 0.13 & 2.53 & 14.79 & $4,851.76$ & \\
\hline 04/10/02 & 1212 & 1.04 & 3.44 & 13.88 & $4,850.85$ & \\
\hline $04 / 23 / 02$ & 1529 & 0.14 & 2.54 & 14.78 & $4,851.75$ & \\
\hline $04 / 24 / 02$ & 1407 & 0.10 & 2.50 & 14.82 & $4,851.79$ & \\
\hline 06/13/02 & 1000 & 0.29 & 2.69 & 14.63 & $4,851.60$ & \\
\hline 09/11/02 & 1300 & 0.87 & 3.27 & 14.05 & $4,851.02$ & \\
\hline 09/24/02 & 1117 & 0.19 & 2.59 & 14.73 & $4,851.70$ & Before purging. \\
\hline $10 / 22 / 02$ & & -0.05 & 2.35 & 14.97 & $4,851.94$ & \\
\hline 03/06/03 & 1031 & -0.03 & 2.37 & 14.95 & $4,851.92$ & \\
\hline
\end{tabular}

Depth $=3.79 \mathrm{ft}$ below land surface

Land surface elevation = 4,851.0 ft (above $\mathrm{msl}$ ); $14.0 \mathrm{ft}$ (gage datum)

Measuring point elevation - 4,852.26 ft (above $\mathrm{msl}$ ); $15.29 \mathrm{ft}$ in gage datum

Measuring point to land surface $=\mathbf{1 . 3 0} \mathrm{ft}$

\begin{tabular}{cclllll}
\hline Date & Time & $\begin{array}{c}\text { Water level } \\
\text { below land } \\
\text { surface }\end{array}$ & $\begin{array}{c}\text { Water level } \\
\text { below } \\
\text { measuring } \\
\text { point }\end{array}$ & $\begin{array}{c}\text { Water surface } \\
\text { (in gage } \\
\text { datum) }\end{array}$ & $\begin{array}{c}\text { Water } \\
\text { surface } \\
\text { elevation } \\
\text { (msl) }\end{array}$ & Remarks \\
\hline $01 / 29 / 02$ & 1140 & 0.27 & 1.57 & 13.72 & $4,850.69$ & \\
$01 / 30 / 02$ & & 0.00 & 1.30 & 13.99 & $4,850.96$ \\
$01 / 31 / 02$ & 1255 & 0.05 & 1.35 & 13.94 & $4,850.91$ & \\
$03 / 13 / 02$ & 1345 & 0.09 & 1.39 & 13.90 & $4,850.87$ & \\
$04 / 10 / 02$ & 1232 & 0.03 & 1.33 & 13.96 & $4,850.93$ & \\
$04 / 23 / 02$ & 1714 & 0.11 & 1.41 & 13.88 & $4,850.85$ & \\
$06 / 13 / 02$ & 0945 & 0.19 & 1.49 & 13.80 & $4,850.77$ & \\
$09 / 11 / 02$ & 1215 & 2.25 & 3.55 & 11.74 & $4,848.71$ & \\
$09 / 24 / 02$ & 1215 & 0.29 & 1.59 & 13.70 & $4,850.67$ & Before purging. \\
$10 / 22 / 02$ & & 0.05 & 1.35 & 13.94 & $4,850.91$ & \\
$03 / 06 / 03$ & 1015 & 0.19 & 1.49 & 13.80 & $4,850.77$
\end{tabular}


Appendix Table A2. Water-level data from shallow wells and piezometers at the Mt. Pisgah campground, Haywood County, North Carolina.-Continued

[Values are in feet; USGS, U.S. Geological Survey; ft, feet; msl, mean sea level; >, greater than]

Well 7; USGS site no. 352428082452601; County no. HW-72

Depth $=6.40 \mathrm{ft}$ below land surface

Land surface elevation $=4,845.7 \mathrm{ft}$ (above $\mathrm{msl}$ ); $8.7 \mathrm{ft}$ (gage datum)

Measuring point elevation $=4,848.25 \mathrm{ft}$ (above $\mathrm{msl}$ ); $11.28 \mathrm{ft}$ in gage datum

Measuring point to land surface $=2.60 \mathrm{ft}$

\begin{tabular}{ccclccc}
\hline Date & Time & $\begin{array}{c}\text { Water level } \\
\text { below land } \\
\text { surface }\end{array}$ & $\begin{array}{c}\text { Water level } \\
\text { below } \\
\text { measuring } \\
\text { point }\end{array}$ & $\begin{array}{c}\text { Water surface } \\
\text { (in gage } \\
\text { datum) }\end{array}$ & $\begin{array}{c}\text { Water } \\
\text { surface } \\
\text { elevation } \\
\text { (msl) }\end{array}$ & Remarks \\
\hline $01 / 28 / 02$ & & 4.27 & 6.87 & 4.41 & $4,841.38$ \\
$01 / 30 / 02$ & 1240 & 4.83 & 7.43 & 3.85 & $4,840.82$ \\
$01 / 31 / 02$ & 1235 & 4.89 & 7.49 & 3.79 & $4,840.76$ \\
$03 / 13 / 02$ & 1300 & 4.35 & 6.95 & 4.33 & $4,841.30$ & \\
$04 / 10 / 02$ & 1200 & 4.58 & 7.18 & 4.10 & $4,841.07$ & \\
$04 / 23 / 02$ & 1457 & 5.18 & 7.78 & 3.50 & $4,840.47$ & \\
$06 / 13 / 02$ & 0940 & 5.40 & 8.00 & 3.28 & $4,840.25$ & \\
$09 / 11 / 02$ & 1200 & 5.92 & 8.52 & 2.76 & $4,839.73$ & Before purging. \\
$09 / 24 / 02$ & 1020 & 4.26 & 6.86 & 4.42 & $4,841.39$ \\
$10 / 22 / 02$ & & 4.94 & 7.54 & 3.74 & $4,840.71$ & \\
$03 / 06 / 03$ & 1041 & 2.83 & 5.43 & 5.85 & $4,842.82$ & \\
\hline
\end{tabular}

Depth $=1.18 \mathrm{ft}$ below land surface

Land surface elevation = 4,848.5 ft (above $\mathrm{msl}$ ); $11.5 \mathrm{ft}$ (gage datum)

Measuring point elevation = 4,849.19.ft (above $\mathrm{msl}$ ); $12.22 \mathrm{ft}$ in gage datum

Measuring point to land surface $=0.75 \mathrm{ft}$

\begin{tabular}{cllllll}
\hline Date & Time & $\begin{array}{c}\text { Water level } \\
\text { below land } \\
\text { surface }\end{array}$ & $\begin{array}{c}\text { Water level } \\
\text { below } \\
\text { measuring } \\
\text { point }\end{array}$ & $\begin{array}{c}\text { Water surface } \\
\text { (in gage } \\
\text { datum) }\end{array}$ & $\begin{array}{c}\text { Water } \\
\text { surface } \\
\text { elevation } \\
\text { (msl) }\end{array}$ & Remarks \\
\hline $01 / 30 / 02$ & & 0.59 & 1.34 & 10.88 & $4,847.85$ \\
$01 / 31 / 02$ & & 0.64 & 1.39 & 10.83 & $4,847.80$ \\
$03 / 13 / 02$ & 1310 & 0.08 & 0.83 & 11.39 & $4,848.36$ \\
$04 / 10 / 02$ & 1210 & -0.15 & 0.60 & 11.62 & $4,848.59$ \\
$04 / 23 / 02$ & & 0.89 & 1.64 & 10.58 & $4,847.55$ \\
$06 / 13 / 02$ & & 1.05 & 1.80 & 10.42 & $4,847.39$ \\
$09 / 11 / 02$ & & 1.15 & 1.90 & 10.32 & $4,847.29$ \\
$03 / 06 / 03$ & 1037 & 0.11 & 0.86 & 11.36 & $4,848.33$
\end{tabular}


Appendix Table A2. Water-level data from shallow wells and piezometers at the Mt. Pisgah campground, Haywood County, North Carolina.-Continued

[Values are in feet; USGS, U.S. Geological Survey; ft, feet; msl, mean sea level; >, greater than]

Piezometer B; USGS site no. 352425082452301; County no. HW-74

Depth not measured; less than $2 \mathrm{ft}$ below land surface

Land surface elevation $=4,847.9 \mathrm{ft}$ (above $\mathrm{msl}$ ); $10.9 \mathrm{ft}$ (gage datum)

Measuring point elevation $=4,848.63 \mathrm{ft}$ (above $\mathrm{msl}$ ); $11.66 \mathrm{ft}$ in gage datum

Measuring point to land surface $=0.75 \mathrm{ft}$

\begin{tabular}{cllllll}
\hline Date & Time & $\begin{array}{c}\text { Water level } \\
\text { below land } \\
\text { surface }\end{array}$ & $\begin{array}{c}\text { Water level } \\
\text { below } \\
\text { measuring } \\
\text { point }\end{array}$ & $\begin{array}{c}\text { Water surface } \\
\text { (in gage } \\
\text { datum) }\end{array}$ & $\begin{array}{c}\text { Water } \\
\text { surface } \\
\text { elevation } \\
\text { (msI) }\end{array}$ & Remarks \\
\hline $01 / 30 / 02$ & & 0.34 & 1.09 & 10.57 & $4,847.54$ \\
$01 / 31 / 02$ & 1325 & 0.40 & 1.15 & 10.51 & $4,847.48$ \\
$03 / 13 / 02$ & 1311 & -0.26 & 0.49 & 11.17 & $4,848.14$ \\
$04 / 10 / 02$ & 1211 & -0.53 & 0.22 & 11.44 & $4,848.41$ \\
$06 / 13 / 02$ & & 0.08 & 0.83 & 10.83 & $4,847.80$ \\
$09 / 11 / 02$ & & 0.46 & 1.21 & 10.45 & $4,847.42$ \\
$03 / 06 / 03$ & 1037 & 0.32 & 1.07 & 10.59 & $4,847.56$ \\
\hline
\end{tabular}

